\title{
From Padmasambhava to Gö Tsangpa: Rethinking Religious Patronage in the Indian Himalayas between the 8 th and 13 th Centuries
}

\author{
Verena Widorn
}

Authenticity - in all its various aspects ${ }^{2}$ - seems to be one of the most required criterions when analysing an object of art. The questions of authenticity of provenance and originality in particular are of major importance for western art historians. The interest in genuine workmanship, the knowledge of an exact date, and chronology keep scholars occupied in their search for proper timelines and the artistic lineages of monuments and artefacts. The time of

1 I especially wish to express my gratitude to Carmen Meinert and her team for the generous invitation to the start-up conference of her ERC project BuddhistRoad, which gave me the opportunity to present and now to publish a topic that has been on my mind for several years and was supported through several field trips to pilgrimage sites in Himachal Pradesh. Still, this study is just a first attempt to express my uneasiness with the manner in which academic studies forces western concepts of authenticity onto otherwise hagiographic ideals. I am also thankful to Max Deeg and Lewis Doney for their critical and efficient comments on my paper during the conference. I especially thank Erika Forte for all her helpful suggestions and her constant encouragement. I am particularly grateful to Melissa Kerin, who in many discussions stimulated my thinking about the concept of western and non-western geography of art and who made essential comments to this paper. I equally appreciate the suggestions and helpful hints by Tasha Kimmet. My research trips to Lahul and Kinnaur were generously financed by the Austrian Science Fund (FWF) in the framework of different research projects on the cultural history of the Western Himalaya directed by Deborah Klimburg-Salter, who encouraged and has always supported my interest in the sacred environment of the region.

2 The concept of authenticity is not only difficult to define, but also quite controversial in various disciplines. While the historical sciences consider authenticity mostly in the sense of 'historical truth,' 'genuineness,' and 'originality' as counterparts to 'false documents/fake news,' 'forgery,' or 'imitation,' the term is exposed in the postmodern discourse primarily as a construct of subjective perceptions. For anthropology, Regina Bendix comprehends the question of authenticity as the root discourse of the discipline, albeit with a broad and elusive semantic domain, due to the moral, emotional, or even romanticising conceptualisation of the term. See Regina Bendix, "Diverging Paths in the Scientific Search for Authenticity," Journal of Folklore Research 29.2 (1992): 104-105. Susanne Knaller also notes the intricacies of the concept of authenticity "in that it enables to contaminate empirical, interpretative, evaluative and normative moments in a barely unlockable way." See Susanne Knaller, Ein Wort aus der Fremde. Geschichte und Theorie des Begriffs Authentizität (Heidelberg: Winter, 2007), 9. 
commission and the role of patronage are considered not only historically and politically decisive factors for iconography and style but also reveal certain information about the social, economic, and ideological backgrounds of the creation process. Outside of the western art historical sphere, authenticity can be expressed and valued differently. Historic and artistic values are minor components in a devotional context and often mean little or nothing to local communities' current spiritual relationship to the artefact or building. What tend to be important characteristics from an academic perspective, namely when, how, and by whom an object was made, seem less relevant for communities of devotion, who are concerned with the ritual potency of a cultic icon-especially on a personal level for the individual practitioner.

The association of monuments with religious personalities whose life narrations are hagiographic and not historical accounts, is a frequent phenomenon in the Western Himalayas. In this paper, as a case study, I employ an art historical perspective to discuss and compare the religious landscape and the Buddhist legacy of two regions, namely the valleys of Kinnaur and Lahul (at present of the Indian state of Himachal Pradesh) (map 6.1). Both districts share several common features that allow for a meaningful comparison, such as a similar topographical setting and a location at the periphery of the former Tibetan Empire in the 8th century, the West Tibetan Kingdom of Purang-Guge in later centuries, and the Ladakhi reign at the turn of the first millennium. Both districts are traversed by important trade (and at present-day tourist) routes, which also double as pilgrimage routes, connecting the plains of India with the high mountains of the Himalayan and Zanskar Ranges. These corridors of trade and pilgrimage helped to establish cultural exchanges among these areas. A mixed population of Buddhists and Hindus have settled in both regions. Thus vital religious centres and Buddhist strongholds have developed there in the last millennium - although the boundaries between the different schools and even faiths often blur.

Kinnaur and Lahul share a common artistic heritage, which is the focus of this discussion. With references to oral traditions, daily rituals, local beliefs, and art historical evidence, I present current perceptions of three Buddhist figures of the Western Himalaya, namely the Indian Tantric ascetic Padmasambhava/Guru Rinpoche (8th c.), the Western Tibetan translator Rinchen Zangpo (ca. 985-1055, Tib. Rin chen bzang po), and the Tibetan yogi and pilgrim Gö Tsangpa (ca. 1189-1258, Tib. rGod tshang pa). By shifting my analysis away from chronology and western conceptions of authenticity, and by embracing local knowledge and history, this essay contributes a Baxandall-like study $^{3}$ that focuses on the mechanisms that shape the religious landscape of

3 The art historian Michael Baxandall formulated the concept of the 'Period Eye,' arguing that works of art should be looked at and described by considering the cultural factors and conven- 


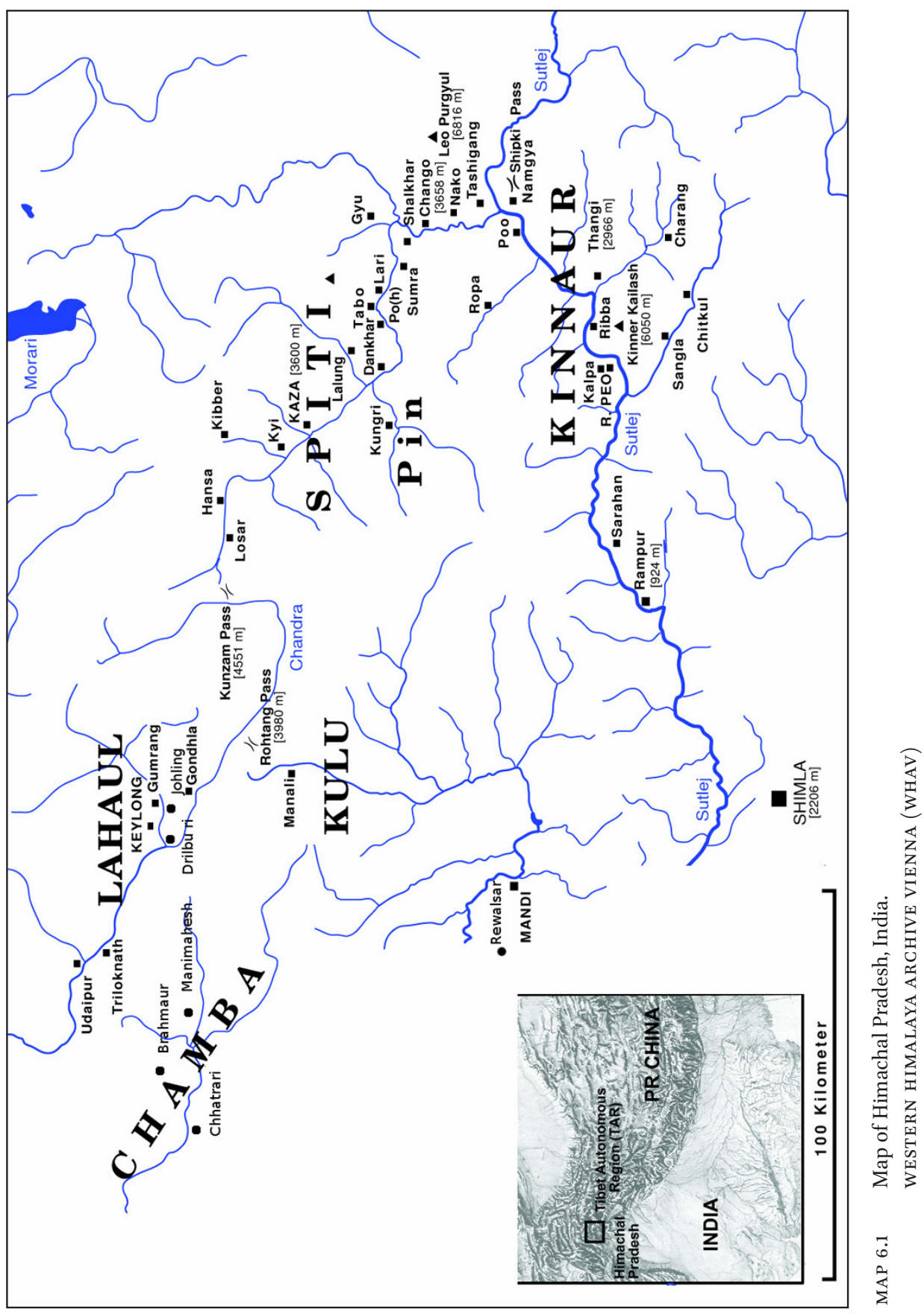


this area and explains the handling of cultural heritage in a sacred geography. Using a method that prioritises the lived experience of these sites and hagiographic accounts of them, this paper contributes to identifying and using categories and materials of analysis that stem from and respond to the Western Himalayan context as opposed to perpetuating western-informed categories of art analysis in a quest for chronological and artistic authenticity.

\section{State of Research}

The focus of art historical research in the Western Himalayas is often on ancient remains of rather popular Buddhist monasteries in Ladakh and Spìtī, which provide a relatively well-preserved monastic infrastructure with beautiful wall paintings that date to the end of the 1st and beginning of the 2nd millennium. ${ }^{4}$ While we do have a rather extensive survey of Buddhist art and architecture in Spītī and Ladakh, comparable studies for Kinnaur and Lahul are still missing, partly due to the fact that several monasteries and shrines have been either destroyed or recently restored and repainted. ${ }^{5}$ There are few publications discussing the role of these august Buddhist personalities and local perceptions of them in relation to the artistic evidence in the Western

tions that influence the visual characteristics of an object at a particular point of time. See Michael Baxandall, Painting and Experience in Fifteenth Century Italy: A Primer in the Social History of Pictorial Style (Oxford: Oxford University Press, 1972), 29-32. He states that "if we wish to explain pictures, in the sense of expounding them in terms of their historical causes, what we actually explain seems likely to be not the unmediated picture but the picture as considered under a partially interpretative description. The description is an untidy and lively affair." Baxandall, Painting and Experience, 10-11. Applying this concept to the religious monuments in the Western Himalayas, the description of artefacts should not present an authentic picture of the past, but promote the idea of addressing the relationship between art, architecture, landscape, and the local contemporary concept of patronage.

4 See e.g. the still valid standard references by Roger Goepper and J. Poncer, Alchi Ladakh's Hidden Buddhist Sanctuary (London: Shambala, 1974, reprint 1996): and Deborah KlimburgSalter, Tabo-A Lamp for the Kingdom. Early Indo-Tibetan Buddhist Art in the Western Himalaya (Milan: Skira, 1996) who base their studies on the pioneering works of August $\mathrm{H}$ Francke, Antiquities of Indian Tibet, Part I: Personal Narrative. Of a Journey in 1910 from Simla to Srinagar; Through Kinnaur, Spitī and Ladakh. For the express Purpose of Investigating the Buddhist Antiquities (Calcutta: Superintendent Government Printing, 1914); and Giuseppe Tucci, Indo-Tibetica II. Rin-c'en bzan-po e la rinascita del Buddismo nel Tibet intorno al mille (Rome: Reale Accad. d'Italia, 1933).

5 In the 1970s, the architect Romi Khosla studied the technical and architectural construction of selected Buddhist monasteries in Lahul, providing several ground plans that are mainly out-dated due to heavy restoration and reconstruction work on the buildings in the last few decades. See Romi Khosla, Buddhist Monasteries in the Western Himalaya (Kathmandu: Ratna Pustak Bhandar, 1979), 153-154. 
Himalayan area. ${ }^{6}$ Only a handful of publications bring together artistic evidence and anthropological considerations to provide a more faceted and dynamic picture of the religious practices in the past and present in relation to the material culture of the Western Himalaya. ${ }^{7}$ But the method of purely iconographic or stylistic analysis of artistic masterpieces in Kinnaur (especially Upper Kinnaur) has recently moved to a more interdisciplinary approach that considers the non-hierarchical concept of visual and material culture and the shifting identity of monuments throughout the centuries. ${ }^{8}$

The research and restoration work on the Nako Temple complex in Kinnaur by an international team of conservation experts, architects, and art historians, and by the village community, also reveals a more differentiated insight into the village and its sacred and vernacular architecture. Art historical research in Lahul is still in an early stage. The secular and religious monuments have only

6 Based on the anthropological studies of Elizabeth Stutchbury, Rediscovering Western Tibet. Gonpa, Chorten and the Continuity of Practice with a Tibetan Community in the Indian Himalaya (PhD diss., Canberra, 1991), the translation of the travel accounts of Tibetan pilgrims by Giuseppe Tucci, Travels of Tibetan Pilgrims in the Swat Valley (Rome: Ismeo, 1971), and my own art historical observations, I made a first attempt to reconstruct a possible artistic and religious setting that the Buddhist practitioners might have experienced in Lahul from the 13th to the 17th century: see Verena Widorn, "Traversing the Land of Siddhas and Dakinis-Art Historical Evidence along the Buddhist Pilgrimage Routes through Lahul," in Cultural Flows across the Western Himalaya, ed. Patrick McAllister, Christina Scherrer Schaub, and Helmut Krasser (Vienna: Austrian Academy of Sciences, 2015), 189-235.

7 A first attempt to reassess art historical observations at the Buddhist temple in Ribba, Upper Kinnaur, by considering local folk tales and songs, was made by Deborah Klimburg-Salter, "Ribba, the Story of an Early Buddhist Temple in Kinnaur," in Buddhist Art and Tibetan Patronage, Ninth to Fourteenth Centuries, ed. Deborah Klimburg-Salter and Eva Allinger (Leiden, Boston, Köln: Brill, 2002), 1-28, later followed by Laxman Thakur, "Rin chen Bzang po's Footsteps: Re-Evaluating the Contribution of the Great Translator through Folklore and Archaeology," in Buddhist Himalaya: Studies in Religion, History and Culture. Proceedings of the Golden Jubilee Conference of the Namgyal Institute of Tibetology, Gangtok, 2008, ed. Alex McKay and Anna Blikci-Denjongpa (Gangtok: NIT, 2011), vol. 1, 209-218.

8 While this approach is a rather recent phenomenon with regard to Western Himalayan art, there are already several endeavours for Indian art that seek to destabilise traditional approaches and western conceptions of art, because they limit our understanding of other cultures, see e.g. Pika Gosh, Temple to Love. Architecture and Devotion in Seventeenth-Century Bengal (Bloomington, Indianapolis: Indiana University Press, 2005). For Kinnaur, one should certainly mention two publications by Melissa Kerin, Art and Devotion at a Buddhist Temple in the Indian Himalaya (Bloomington: Indiana University Press, 2015); Melissa Kerin, "Materiality of Devotion: Tibetan Buddhist Shrines of the Western Hima-laya," in Art of Merit: Studies in Buddhist Art and its Conservation, ed. David Park and Kuenga Wangmo (London: Archetype Publications, 2013), 286-296. Both studies point out the organic and interactive aspect of village temples (not only of the Western Hima-laya), where important personalities and teacher are frequently recognised and idolised beyond their sectarian affiliation. 
been selectively studied with a concentration on the more ancient objects. ${ }^{9}$ In the 1970s, the architect Romi Khosla studied the technical and architectural construction of selected Buddhist monasteries in Lahul, providing several ground plans that are partly out-dated, due to heavy restoration and reconstruction work on the buildings in the last few decades.

An exceptional publication is a small booklet released by the Garsha Young Drugkpa Association (YDA) in 2011. Nawang Jinpa meticulously compiled and critically discusses the opinions of different experts on the art and architecture of Lahul, complemented by the local perspectives and religious concepts of villagers and the Buddhist community. The respectful veneration of artefacts and sacred geography is evident on each page and reminds us that we are dealing with a living tradition that is subject to fluctuations, changes, and adaptions of religious systems over time. As the Garsha Young Drukpa Association explains:

Although we explore written records, we have not relied solely on an academic approach because modern academism easily leads into deserts where the succulent water of faith and the nectar of miracles are regarded as highly suspect. For a pilgrim, such an approach is also suspect, because it is bound to errors and narrow views. [...] Thus in academic art and religious history of Lahaul, updates are constant. ${ }^{10}$

Today, Lahul is a subdivision of the district of Lāhaul-Spìtī and consists of three valleys named after the rivers that run through the region. While the population of the Bhaga and the Chandra Valley is nowadays mainly Buddhist, the inhabitants of the Chandrabhaga Valley, which was part of the neighbouring Chamba district for several centuries, are mainly Śaivas. The Bhaga Valley is currently a stronghold of the Drukpa Kagyü School (Tib. 'brug pa bka' brgyud pa). The centre of the sacred landscape in Lahul is the holy mountain

9 See e.g. Deborah Klimburg-Salter, "Tucci Himalayan Archives Report, 2: The 1991 Expedition to Himachal Pradesh," East and West New Series 44.1 (1994): 13-82 or Christian Luczanits, “Another Rin chen bzang po Temple?" East and West 44.1 (1994): 83-98, who were travelling through Lahul following the footsteps of Giuseppe Tucci's expedition of 1931 .

10 Garsha Young Drukpa Association (YDA), Garsha, Heart Land of the Dakinis (Kyelong: Garsha Young Drukpa Association, 2011). 


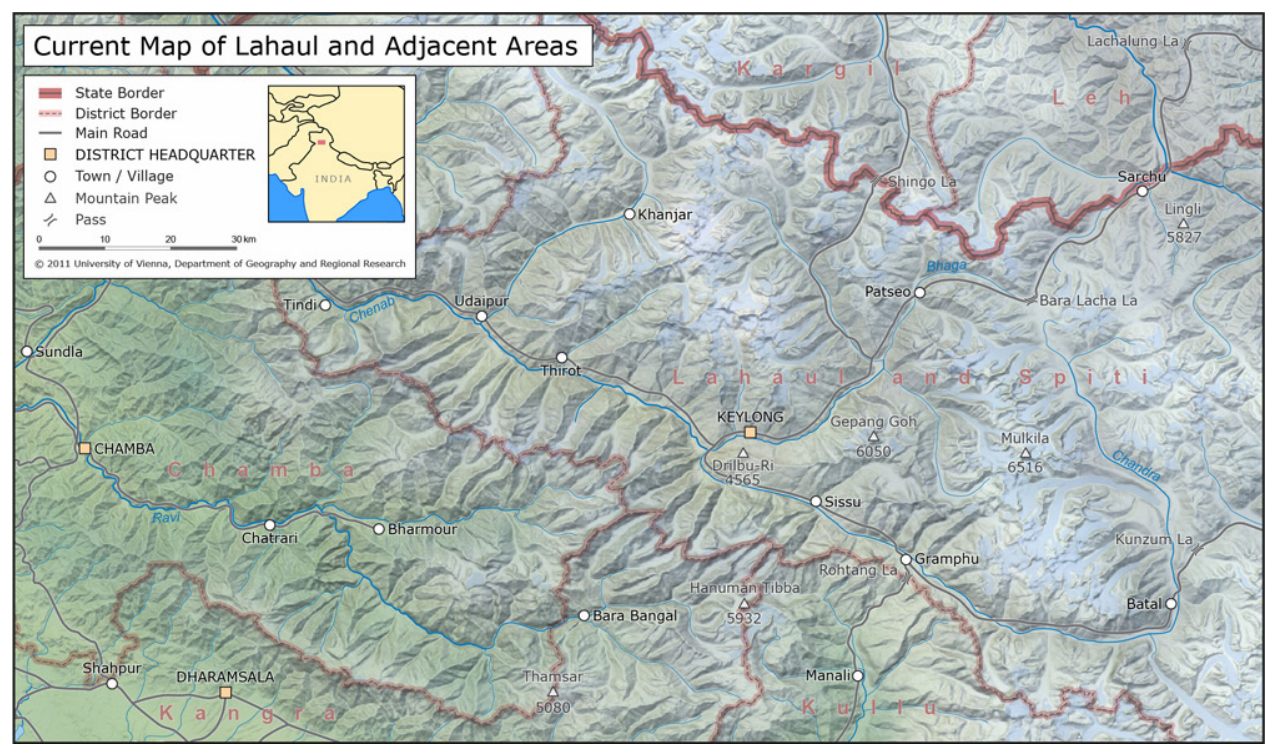

MAP 6.2 Map of Lahul, India.

CULTURAL HISTORY INFORMATION SYSTEM (CHIS)

Drilburi-forming a religious trinity with the Buddhist shrine of Triloknath and the Hindu shrine of Mirkulā Devī in Udaipur (map 6.2). ${ }^{11}$

In the neighbouring district of Kinnaur, despite the fact that scholars focusing on the region concentrate on its Buddhist heritage, at present the majority of the population is Hindu, around 85 percent. ${ }^{12}$ Nevertheless, there are important Buddhist establishments not only in Upper Kinnaur but also in the

11 By the local Buddhist tradition, Mt. Drilbu (Gandhola) is considered the place of the Buddha's Body associated with Cakrasamvara, while Triloknath is the place of Speech associated with Avalokiteśvara, and Udaipur is considered the place of Mind/Heart of Vajravārāhī. Furthermore, a place in or near Udaipur is also considered to be one of the twenty-four holy tìrthas in India, associated with the vajrakāya. According to various Tantric schools, the vajra-body of the Buddha is divided into twenty-four limbs, each referring to a sacred site. The Mirkulā Devī Temple, or at least its location, corresponds to the toes of the vajrakāya and has, therefore, become a pilgrimage centre of trans-national interest for Buddhists, despite its Hindu origin. All three sites are also visited by Hinduslargely for general purification, but also for the wish-granting characteristic of a pilgrimage site, guaranteeing fertility, abundance, and prosperity. See Widorn, "Traversing the Land of Siddhas and Dakinis," 216.

12 See Census of India and also Alex McKay, Kailas Histories. The Renunciate Traditions and the Construction of Himalayan Sacred Landscape (Leiden: Brill, 2016), 180. 


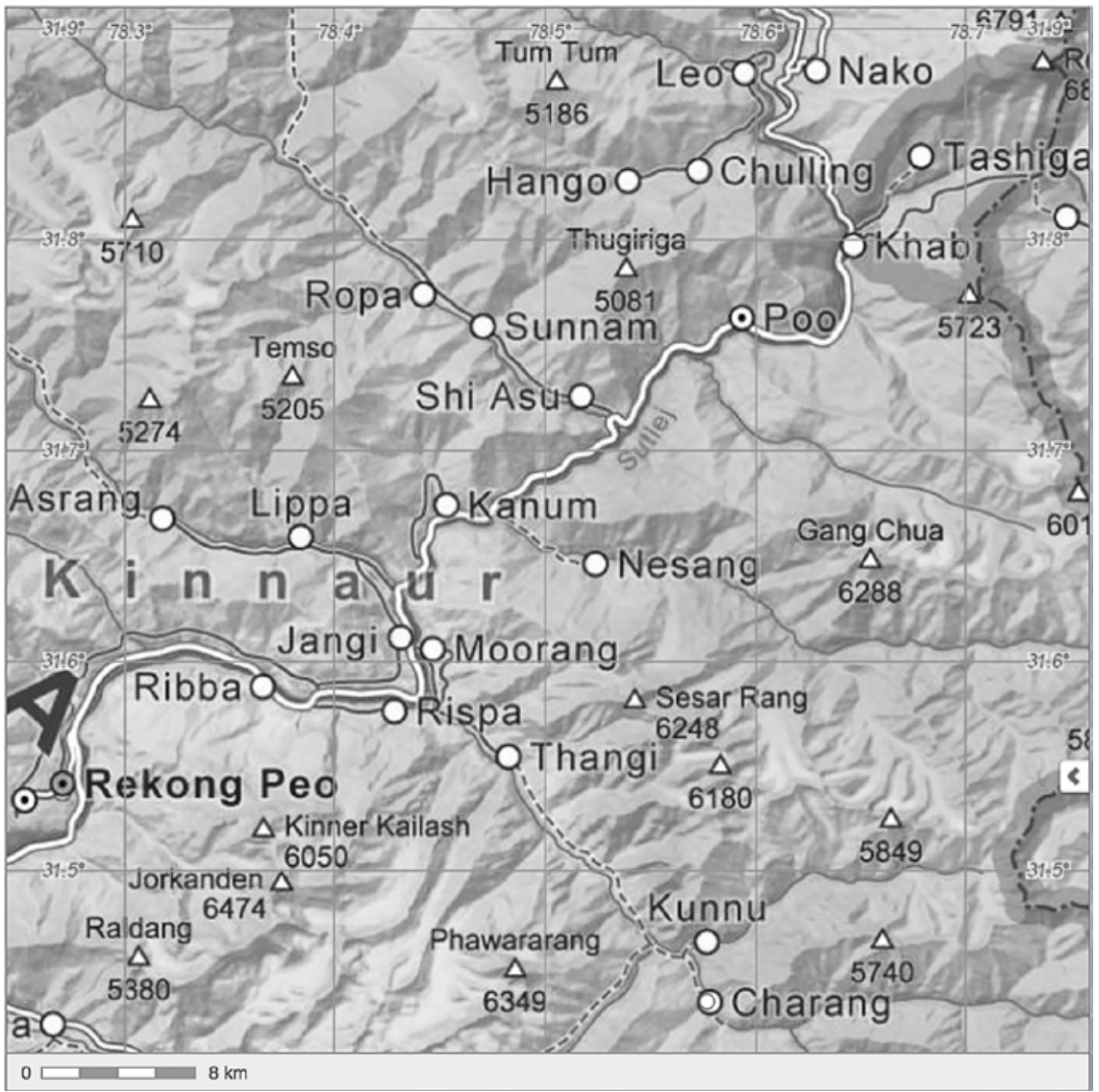

MAP 6.3 Map of Kinner Kailash, India.

CHIS

southern Sangla and Baspa Valley, situated along the circumambulation routes of the holy mountain, the so-called 'Kinner' Kailash (map 6.3).13

\subsection{Padmasambhava}

Buddhism is generally said to have been first introduced into the Indian Himalaya by Nāgārjuna (fl. ca. 150-250) in the 2nd century and later revived by the

13 Alex McKay, who studied the different Kailash mountains in the Himalayan area, explains that the local people not only consider Kinner Kailash to be the abode of Siva but also associate it with the dead ancestors of the community. See McKay, Kailas Histories. McKay points out that the predominant character of the modern pilgrimage around Kinner Kailash is promoted as Saivite and that it follows the Hindu ritual calendar, but that it also has an explicit Buddhist component, proceeding via several ancient Buddhist temples. 
legendary teacher Padmasambhava in the 8th century. In order to understand the development of Buddhism in the Indian Himalayas from the 1oth century onward, one certainly has to comment on the role of Padmasambhava-especially on all the uncertainty about his real and mystical life, his influence on religious orders, and his position in the political system of Tibet and Northern India.

Within the religious traditions of the Indian Himalayas, there is a general belief that the Indian master of Tantric Buddhism, Padmasambhava, passed through the region on his way to Tibet, where he had been invited by the Tibetan King Tri Songdétsen (r. 742-ca. 8oo, Tib. Khri Srong lde bstan) on the advice of the Indian Buddhist philosopher Sāntarakșita (725-788). Padmasambhava's special magical abilities gained through Tantric meditation and his ability to tame the enemy demons and therefore strengthen Buddhism, are often referred to. ${ }^{14}$ In recent years, more and more doubts have emerged about the existence of Padmasambhava as an historic person. Due to his mystical character in his life stories, Friedrich Bischoff was among the first to argue that Padmasambhava was an invention of later centuries and only a kind of religious idea. ${ }^{15}$ The legendary form of his biographies can best be understood as texts to be read as spiritual textbooks for Buddhist followers and not

14 Rob Mayer points to the fact that not all early Buddhist texts were positive about Padmasambhava's role in Tibet. The important historical text the $d B a^{\prime} b z h e d$ [Testament of the $\mathrm{Ba}$ ] states that the great Tantric master was not well received in the south of Tibet, and he was even requested to return to India "since his display of powers creates anxiety and hostility in the minds of the Emperor and his ministers." See Robert Mayer, "We Swear our Grandparents were there!' (Or, What Can the Sex Pistols Tell Us about Padmasambhava?) The Making of Myth in 1oth Century Tibet and 2oth Century England," in The Illuminating Mirror, Tibetan Studies in Honour of Per K. Sørensen on the Occasion of his 65th Birthday, ed. Olaf Czaja and Guntram Hazod (Wiesbaden: Ludwig Reichert Verlag, 2015), 341-342. Mayer agrees with Mathew Kapstein that one explanation might be that Padmasambhava was a teacher of transgressive Tantric practices very much independent of, and perhaps in opposition to, the Imperial Buddhist program. See Matthew T. Kapstein, The Tibetan Assimilation of Buddhism. Conversion, Contestation, and Memory (New York: Oxford University Press, 2000), 159; and Mayer, "We Swear Our Grandparents were there," 342. During his travel in the region now part of Punjab, Xuangzang (6oo/6o2-664, 玄牀), the famous Chinese pilgrim of the 7 th century, reports on Buddhists living with naked ascetics smeared with ashes from cremation grounds and wearing bones on their heads. David Lorenzen, The Kāpālikas and Kālāmukhas: Two lost Śaivite Sects (New Delhi: Thomson Press, 1972), 15-16. Based on the studies of Alexis Sanderson on Indian Tantrism (especially in Kashmir), Mayer sees Padmasambhava as a practitioner of Mahāyoga Tantra at a time when the Śaiva-influenced käpälika forms of Buddhist Tantrism gained popularity south of the Himalaya, and later in the 9th century became prevalent in Tibet. the Csoma de Körös Symposium, ed. Louis Ligeti (Budapest: Akademiai Kiado, 1978), 31. 
necessarily as historiographical works. Researchers such as Peter Schwieger, ${ }^{16}$ Ronald Davidson, ${ }^{17}$ Jacob Dalton, ${ }^{18}$ and Alex McKay ${ }^{19}$ consider the phenomenon of Padmasambhava and the conception of magical acting, in light of a cultural, historical, and socio-political context that covers not only the past but also considers new trends.

Padmasambhava's presence in the Indian Himalayas seems to be proven by the Padma bka'i thang yig [Testament of Padmasambhava], one of the treasure texts, a type of text said to have been hidden by Padmasambhava so that it could be discovered at a time in the future when Tibet was prepared to receive the text's teachings. The Testament of Padmasambhava, discovered by Orgyen Lingpa (1323-ca. 136o, Tib. O rgyan gling pa) in 1352 in the Yarlung Valley, contains a list of places that were supposedly visited by the great master. ${ }^{20}$ Tobdan refers to another ancient Buddhist text related to Padmasambhava, the bLon po bka' yi thang yig [Legends of the Ministers], which mentions the name of Gandhola in Lahul. ${ }^{21}$

\subsection{Rinchen Zangpo}

The other figure of great-but probably regional-renown in the Western Himalaya is the translator Rinchen Zangpo, an allegedly charismatic and energetic figure, who had a following of disciples and the support of powerful patrons, such as the religious king Yéshe Ö (ca. 947-ca. 1024), Tib. Ye shes 'od). From the late 1oth century onwards, Tibetan Buddhism expanded in this region through the kings of Purang-Guge and the nobility, who founded monasteries and temples. The $m N g a$ ' ris rgyal rabs [Royal Genealogies of Ngari], ${ }^{22}$ dated to the end of the $15^{\text {th }}$ century, describes the political dominance of Yéshe

16 Peter Schwieger, "Geschichte als Mythos - Zur Aneignung von Vergangenheit in der tibetischen Kultur. Ein kulturwissenschaftlicher Essay," Asiatische Studien 54.4 (2001): 945973 .

Ronald M. Davidson, Indian Esoteric Buddhism: A Social History of the Tantric Movement (New York: Columbia University Press, 2002); Ronald M. Davidson, Tibetan Renaissance. Tantric Buddhism in the Rebirth of Tibetan Culture (New York: Columbia University Press, 2005).

18 Jacob P. Dalton, "The Early Development of the Padmasambhava Legend in Tibet: A Study of IOL Tib J 644 and Pelliot Tibétain 307," Journal of the American Oriental Society 124.4 (2004): 759-773; Jacob P. Dalton, The Taming of the Demons. Violence and Liberation in Tibetan Buddhism (New Haven, London: Yale University Press, 2011).

19 McKay, Kailas Histories.

$20 \quad$ Detlef I. Lauf, "Zur Geschichte und Kunst Lamaistischer Klöster im Westhimalaya." Asiatische Studien 25 (1971): 367.

21 Tobdan. History and Religions of Lahul (New Delhi: Books Today, 1984).

22 For translation and an extensive commentary on the genealogy, see Roberto Vitali, The Kingdoms of Gu-ge Pu-hrang According to mNga'ris gyal rabs by Gu-ge mkhan-chen 
$\ddot{O}$ and his religious reformations in Guge and the adjacent region..$^{23}$ This process, in Tibetan historiography referred to as the second diffusion of Buddhism (Tib. phyi dar), included the foundation of monastic centres and Buddhist shrines, the institutionalisation of these religious establishments, and the suppression of Tantric rituals brought by practitioners such as the legendary and highly venerated Padmasambhava to the Indian Himalayas, where they intermingled with local belief and the worshiping of territorial deities. ${ }^{24}$ Dalton argues that the development of Buddhism from the 8th to the middle of the 1oth centuries was the cultural foundation for later forms of Tibetan Buddhism, since religion could be practiced at that time without clerical and aristocratic influence. ${ }^{25}$ It became more liberal and open to the inclusion of local rituals. Yéshe Ö, however, sought to prevent these 'old, indigenous' practices (including death rituals) from infiltrating his new religious ideas. Through the translation and canonisation of Sanskrit texts into Tibetan, and the dissemination of the Buddhist teachings through edicts and the newly established monasteries, Yéshe Ö and his key agent, the great translator Rinchen Zangpo, created a buddhocratic empire that commissioned artisans and craftsman from Kashmir and from local workshops. Rinchen Zangpo is credited with the foundation of 108 temples, an auspicious number for Tibetans. Born in the region of Ngari (Tib. mNga' ris), his life dates are pretty much secure based on

Ngag-dbang graps-pa (Dharamsala: Tho-lin dpal dpe med lhun gyis grub pa'i gtsug lag khan lo 1000 'khor ba'i rjes dran mdzad sgo'i go sgrig tshogs chun gis dpar skrun źus, 1996).

23 The early political history of Kinnaur in the West of the Guge region/Kingdom is not fully clear. Although the royal chronicles of the Bashahr Dynasty (1412-1956) and the ranas or rajas who ruled the state during the British Raj up to the 1947 , claim an unbroken dynastic rule of 120 generations - it seems that the Western Tibetan kings extended their territory to the vicinity of Kinner Kailash until the collapse of the Guge Kingdom until the mid-17th century.

24 Seyfort Ruegg presents three models that describe the relation of pan-Indian and local gods to Buddhism: the substratum model, the borrowing model, and the agonistic or hostile model. See David Seyfort Ruegg, The Symbiosis of Buddhism with Brahmanism/Hinduism in South Asia and of Buddhism with Local Cults in Tibet and the Himalayan Region (Vienna: Austrian Academy of Sciences, 2008), viii. The first one suggests a common ground of religious belief and practice in India, which is shared by Buddhism and Brahmanism. The latter model seems to be another possibility to apply to the Himalayas in the tenth century, to demonstrate the superiority of Buddhism over local beliefs after a political and religious chaotic period, in Tibetan historiography referred to as time of fragmentation (Tib. sil bu'i dus). This last sentence needs to be edited. It is not clear what you mean by the second half of the sentence, "to demonstrate the...chaotic period." 
historical accounts and several biographies written by his followers. ${ }^{26}$ Several buildings in the Indian Himalayas, especially in Kinnaur, are considered to have been founded by him.

\subsection{Gö Tsangpa}

From the 12th/13th century onwards, the relocating of Tibetan pilgrimage from the biographical sites of the Buddha in the Ganges region to less frequented places in more remote areas, led to a new tradition of Tibetan pilgrimage in the Indian hills. ${ }^{27}$ The landscape became sanctified by magical acts and meditation, and many ancient sites became associated with the mystical power of Tantric yogis. One of the first Tibetan pilgrims who traversed the areas of Kinnaur and Lahul and left a spiritual imprint on the region was the Drukpa Kagyü monk Gö Tsangpa, who travelled through the area on the way from Central or Western Tibet to Oḍdiyāna in the Swat Valley (the assumed birthplace of Padmasambhava). Gö Tsangpa was supposedly an emanation of Milarépa (1040-1123, Tib. Mi la ras pa) and is equally famous for his music and dance performances. The religious history of the Lahul region is closely connected to this personality, who is sometimes even erroneously considered to be from the region. There are several hagiographies describing Gö Tsangpa's pilgrimage from Zhang Zhung to Oḍdiyāna through the Indian hills; the most well-known one is probably the manuscript Giuseppe Tucci located in Spīti in 1933, later published by him in $1971 .{ }^{28}$ Together with the adept Orgyenpa Rinchenpel (ca. 1229-1309, Tib. O rgyan pa rin chen dpal), the Drukpa Kagyü yogi shaped the

26 A translation of the earliest biography of Rinchen Zangpo, together with a list of associated temple foundations, is provided by David Snellgrove and Tadeusz Skorupski in the second volume of their path breaking book. David L. Snellgrove and Tadeusz Skorupski, The Cultural Heritage of Ladakh, Vol. 2: Zangskar and the Cave Temples of Ladakh (Warminster: Aris and Phillips, 1980). Besides his mention in the Deb ther sngon po [Blue Annals], George Nicholas Roerich, The Blue Annals. Part 1 (Calcutta: Royal Asiatic Society of Bengal, 1949), 68-69, further information on Rinchen Zangpo's life and other historical records on the Kingdom of Purang-Guge are discussed in Tsepak Rigzin, "Rinchen Zangpo: The Great Tibetan Translator," Tibet Journal 9.3 (1984): 28-37; Vitali Roberto, The Kingdoms of Gu.ge Pu.hrang and recently David Thomas Pritzker, "Canopy of Everlasting Joy: An Early Source in Tibetan Historiography and the History of West Tibet" (PhD diss., University of Oxford, 2017).

27 Toni Huber, The Holy Land Reborn. Pilgrimage and the Tibetan Reinvention of Buddhist India (Chicago, London: The University of Chicago Press, 2008).

28 The itinerary (one out of fourteen) found by Tucci is named rGyal brgod ts'an pa'i rnam thar gnas bsuds pai sgron me [Lamp that Integrates the Biography of Gö Tsangpa] and is a separate chapter of the dKar rgyud rnams kyi rnam thar gyi sgron me. See Tucci, Travels of Tibetan Pilgrims in the Swat Valley (Rome: IsmeO, 1971), 374. 
sacred geography and collective memory of Lahul in such a formative way that his impact and presence is still felt there today. ${ }^{29}$

Traces of these Buddhist masters can be found everywhere in the artistic heritage of Lahul and Kinnaur Valleys. The three figures mentioned above are highly venerated and frequently depicted in wall paintings, scroll paintings, and sculptures in Buddhist shrines and monasteries. ${ }^{30}$ Additionally, there are some places in the Indian Himalaya that are particularly dedicated to and associated with their presence and patronage. I present the most prominent examples in the following sections in order to show how closely these objects and monuments are connected to the landscape and geological peculiarities of the region and how art is instrumental to sanctifying certain sites and creating a sacred geography of art. ${ }^{31}$

29 The YDA points out that there is "such a vivid memory of his amazing feats that they [the local people] believe that he was around just a few generations ago." See Garsha Young Drukpa Association (YDA), Garsha, Heart Land of the Dakinis, 62.

30 None of these presentations were produced coeval to the (assumed) life-times of the three prominent personalities. One interesting example is the pictural programme of the oldest paintings in the monastery of Tabo, Spìti. Although the monastery is considered to be one of his foundations, Rinchen Zangpo is obviously not presented in the depiction of important historical figures and donors in the old entry hall of the main temple. The wall paintings dated to the foundation phase of the late gth or early 1oth century show a group of patrons and clan members of noble families, including Yéshe Ö and his two sons. The absence of Rinchen Zangpo in this assembly is explained by Klimburg-Salter by his time in Kashmir and his absence from Guge between ca. 987 and 1000, and from 1016 to 1021, as suggested by the Italian historian Luciano Petech in contrast to Vitali's slightly different chronology of the Great Translator's biography, see Klimburg-Salter, Deborah, "Imagining the World of Ye shes 'od. 1oth Century Painting in Tabo," in The Cultural History of Western Tibet. Recent Research from the China Tibetology Research Center and the University of Vienna, ed. Deborah Klimburg-Salter et al. (Vienna, Beijing: Austrian Academy of Sciences, 2008), 240.

31 The concept of the sacredness of (Himalayan) landscape in general has been widely discussed by e.g. Niels Gutschow, Axel Michaels, Charles Ramble, and Ernst Steinkellner, eds., Sacred Landscape of the Himalaya (Vienna: Austrian Academy of Sciences, 2003). The 'spatial turn' in art history, however, is not a recent phenomenon but a still debated issue questioning how the meaning of space and the concept of place is related and determined to the creation and characteristic of art and architecture. Thomas DaCosta Kaufmann, in his book Toward a Geography of Art, is rethinking and investigating the notion and role of geography for art historians in an historical dimension. Thomas DaCosta Kaufmann, Toward a Geography of Art (Chicago, London: The University of Chicago Press, 2004). He highlights the conjunction of the temporal with the spatial aspects of objects and monuments and even suggests speaking of a "geohistory" of art; ibid., 13. 

Valleys

The representation of Padmasambhava is omnipresent in the art of the Indian Himalayas. Practically all temples and monasteries have one or more sculptures or paintings of Padmasambhava, typically sitting in the royal position (Skt. lalitāsana), face adorned with a moustache and a goatee, and head covered with a red hat. He is usually holding a Tantric staff (Skt. khațvāinga) and a skull cup (Skt. kapāla) in the left hand and a vajra near his heart in the right hand. But more important than his iconic images are special locations and natural phenomena in the geography that refer to his miraculous acts and presence. Power places, spectacular sites, and unique features in the mountainous landscape of Himachal seem to be specifically predestined for sanctification by the great guru Padmasambhava.

\subsection{Lahul}

One of these special locations is the site of Gandhola in Lahul. Gandhola is at the crossing of three valleys and allows a perfect view down on the cremation ground at the confluence of the Chandra and Bhaga Rivers (fig. 6.1). Eight Great Charnel Grounds are assigned to important events in Padmasambhavas life and the siddhi he received. In Lahul, this place is also associated with him by the local tradition. Equally important and sacred for both Hindus and Buddhist, it is considered a magical site and attracts Tantric practitioners:

For Buddhist yogis, it has been considered a place of power also due to the energy of the currents coming together, enhancing special meditations aimed at uprooting all forms of self concern and grasping. In his biography, the great yogi Rangrik Repa (17th century) narrates how, as he reached this point of his pilgrimage, he remained on that spot for several hours in a state of total contemplative awe. ${ }^{32}$

The small three-storied shrine of Gandhola is situated on the slopes of the holy Mt. Drilbu (Drilburi), high up above the confluence of the rivers and is said to have been founded by Padmasambhava. A famous marble head, today kept in the Tupchiling Monastery just below Gandhola, is attributed to the site and is supposed to have been blessed by him (fig. 6.2). The partly damaged whitemarble object displays the heads of a crowned Buddha or bodhisattva with half closed eyes. Although the crown is quite damaged, one can still guess the vague

32 Garsha Young Drukpa Association (YDA), Garsha, Heart Land of the Dakinis, 27. 


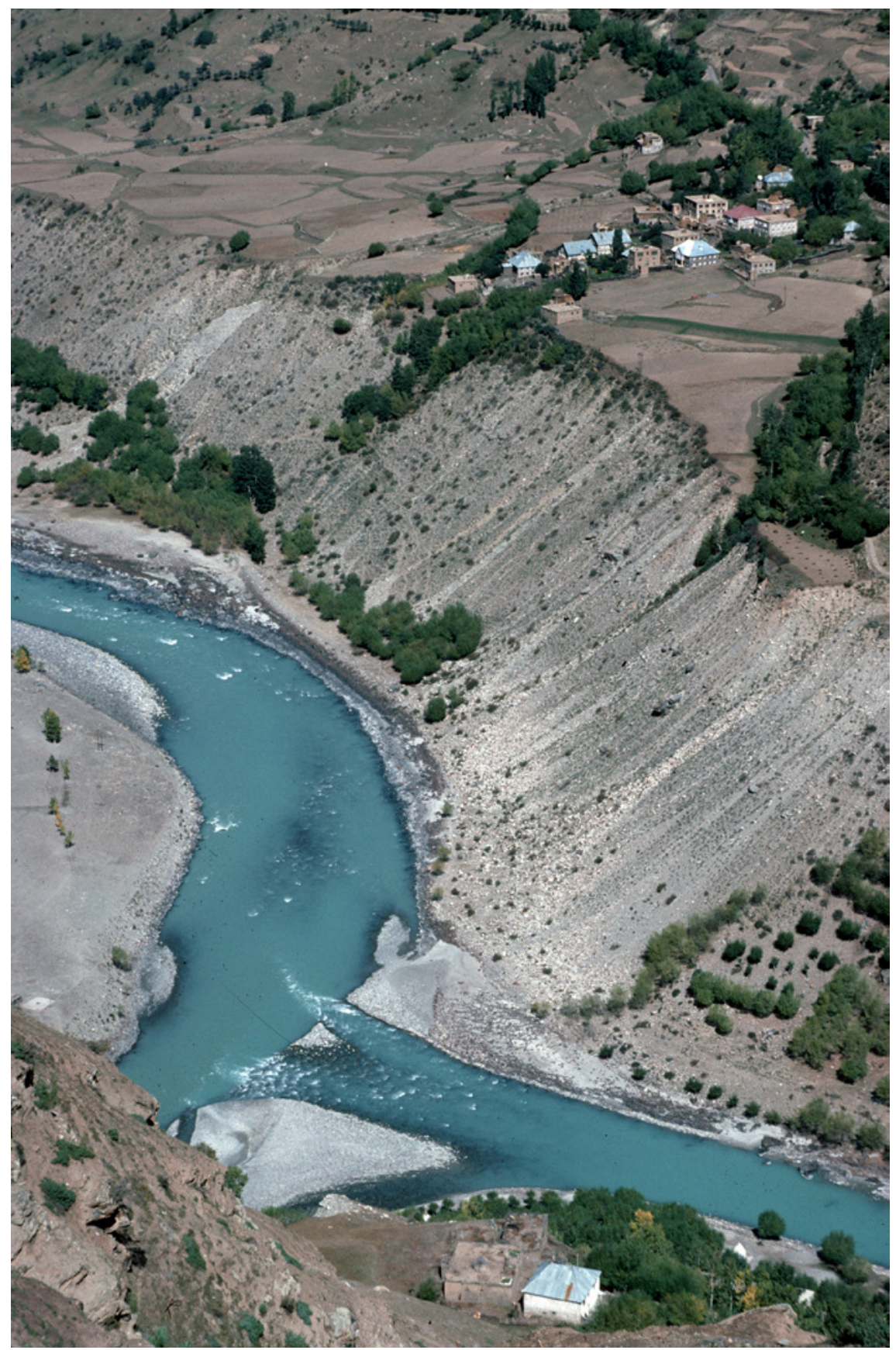

FIGURE 6.1 Confluence of Chandra and Bhaga, view from Gandhola, Lahul. CHRISTIAN LUCZANITS, 1993, WHAV 


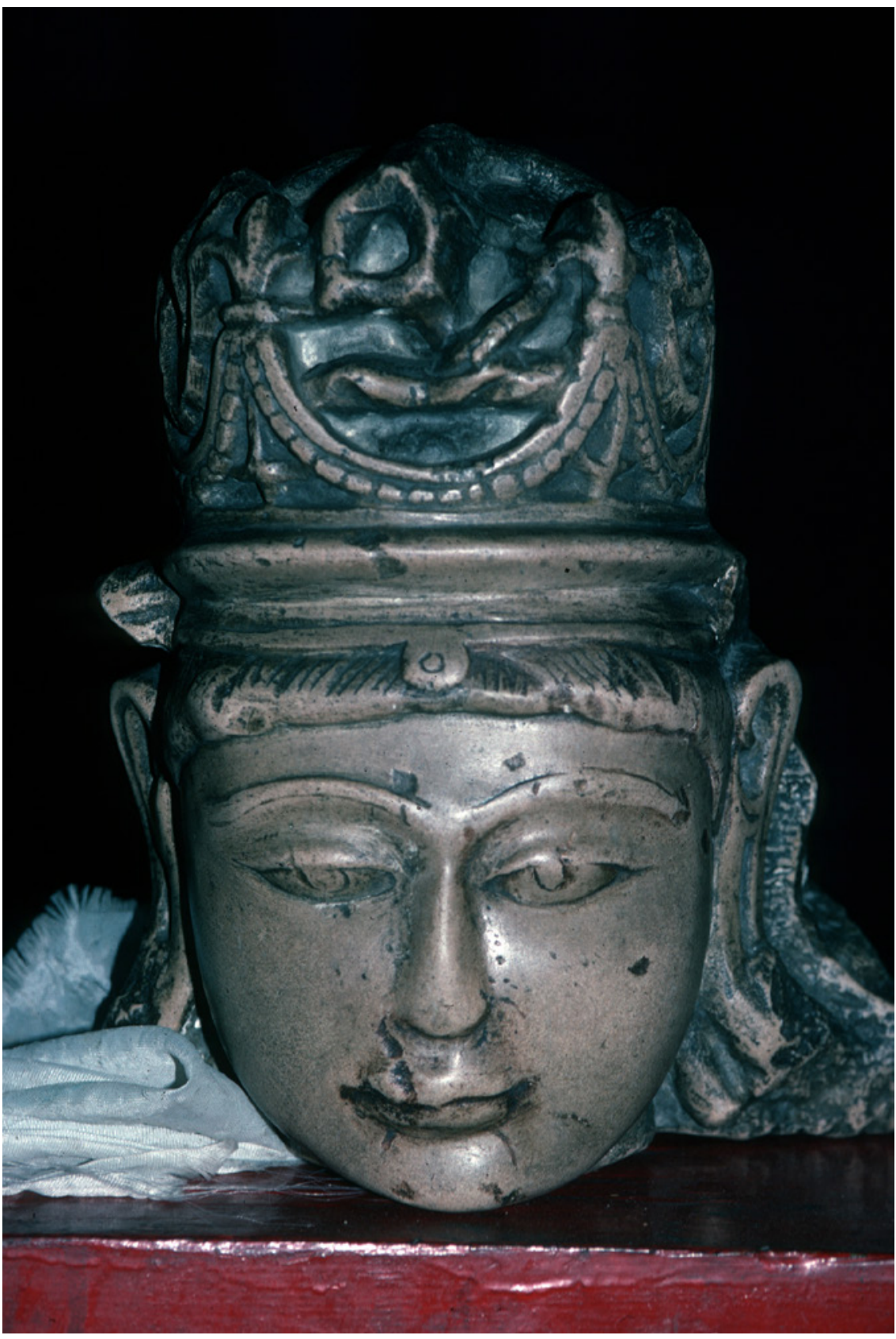

FIGURE 6.2 Marble head of an Avalokiteśvara. Gandhola, Lahul (?) Dated to the 8th century, kept in Tupchiling, Lahul. CHRISTIAN LUCZANITS, 1993, WHAV 
silhouette of a figure with the arms resting on the legs in the lotus seat, probably Buddha Amitābha-indicating that the head might have been part of a statue of Avalokiteśvara. The spiritual importance of the head is surrounded by local legends that evolved in the last few decades, as the narrations about its discovery show. Madanjeet Singh reports that the head was "dug up in the valley below the junction of the rivers Chandra and Bhaga" without giving any further information. ${ }^{33}$ O.C. Handa places this event sometime between 1917 and 1953, and believes that the fragment belonged to a marble Avalokiteśvara sculpture enshrined in the ancient Gandhola Monastery, whose original structure was destroyed in an avalanche. ${ }^{34}$ The marble piece was known to, and maybe even documented by, Henry Lee Shuttleworth when he visited Lahul in the 1920s, since the Moravian missionary Walter Asboe refers to him in a letter to the curator of the former ethnographical Cranmore Museum in Chislehurst, U.K., in the 1930s. ${ }^{35}$ Asboe collected various objects and items of ritual and daily use for the British museum and was explicitly looking for this head in

33 Madanjeet Singh, Himalayan Art. Wall-painting and Sculpture in Ladakh, Lähaul and Spītī, the Siwalik Ranges, Nepal, Sikkim and Bhutan (London, Melbourne: Macmillan, 1968).

34 O.C. Handa, Buddhist Monasteries of Himachal (New Delhi: Indus, 2004), 123. Unfortunately, Handa gives no sources for his story nor mentions any date for the alleged destruction of the possible ancient structure of the monastery.

One of the most comprehensive surveys of the villages and artistic remains in Lahul is provided in the unpublished notes from the Herrnhuter missionary August Hermann Francke, drawing an interesting picture of the region's Buddhist artefacts at the beginning of the 2oth century. See August H. Francke, The Ancient History of Lāhaul (Herrnhut: unpublished, undated); August H. Francke, List of Ancient Monuments Lahul \& Spītī. Archaeological Survey, Panjab and United Provinces Circle (Herrnhut: unpublished, undated, unpublished). While Francke was mainly interested in the Buddhist heritage of the area, the Dutch Sanskritist Jean Philippe Vogel, from the Archaeological Survey of India, with whom he was in constant exchange, was concentrating on the Hindu remains and monuments of the western part of Lahul, which belonged to Chamba State in earlier times. See Jean P. Vogel, Antiquities of Chamba State (Calcutta: Superintendent Government Printing, 1911). Francke also kept close contact and friendship with the British officer and orientalist Henry Lee Shuttleworth, who was travelling the Western Himalayas on behalf of the Indian Civil Service and who was working together with Francke on a planned but never realised forth volume of the Antiquities of Indian Tibet. The first two parts were published by Francke in 1914 and 1926. See also Christian Jahoda, "Archival Exploration of Western Tibet or What Remained of Francke's and Shuttleworth's Antiquities of Indian Tibet," in Pramānakîrtih. Papers Dedicated to Ernst Steinkellner on the Occasion of his 7oth Birthday, ed. Birgit Kellner et al. (Vienna: Austrian Academy of Sciences, 2007), 361-394; and Yannick Laurent, "Henry Lee Shuttleworth (1882-196o) and the History of Spītī," Revue d'Études Tibétaines 41 (2017): 13. It is interesting to notice that although Francke's and Shuttleworth's research on Lahul was only fragmentarily published, it seems that their findings were well known and photographs were frequently circulated provoking succeeding missionaries and collectors to get their hands on certain artefacts. 
order to purchase it and send it to the U.K. Thus far, we do not have any information regarding whether his search was successful or not - the head is still in Lahul, and there are certain rumors that it is kept safe in the Tupchiling Monastery because there were attempts to steal the precious object in the past. The mysteries that twine around all these events - their vague chronology and speculative background-have even increased the local appreciation of the image as a sacred artefact. The Garsha Young Drukpa Association supports the local tradition that considers the discovery, or rather emergence, of the head seventy years ago at the confluence of the rivers to be a miraculous event. ${ }^{36}$

Handa claims that "the head is stylistically and thematically identical to the one [sculpture] at Triloknath and may be coeval." ${ }^{37}$ Handa refers to the marble idol of the shrine at the famous nearby pilgrimage site in the Chandrabhaga Valley, which seems to be a place of worship for Buddhists as well as Hindus for several centuries. ${ }^{38}$ The temple's main image is a six-armed Sugatisamiarśana Lokeśvara ${ }^{39}$ that sits on a high lotus pedestal and displays the gesture of 'wish-granting' (Skt. varadamudrā) with one of his right hands. It is at least in modern times, also venerated by Hindu pilgrims as an image of the ascetic Śiva. The sculpture is difficult to date, but seems to have replaced the original central image, a dark stone Lokeśvara, maybe only after the 17th century. ${ }^{40}$ The marble sculpture is not an exact copy of the black stone image, but follows it in iconography and form. However, apart from the rare use of marble, the fragmented head of Gandhola differs stylistically from both images

36 Garsha Young Drukpa Association (YDA), Garsha, Heart Land of the Dakinis, 28.

37 Handa, Buddhist Monasteries of Himachal, 123.

38 Obviously of Buddhist origin, clearly indicated by the two small Buddhas in the brackets of the columns in front of the sanctum, and the main idol, the Nāgara Temple with the conspicuous tower is clearly more oriented on and influenced by the North Indian temple design than by any Tibetan tradition, and can therefore be dated to a period before the 1oth century. See therefore Verena Widorn and Gerald Kozicz, "The Temple of Triloknath-A Buddhist Nagara Temple in Lahul," South Asian Studies 28.1 (2012): 15-35. This date is also supported by an inscription found inside the temple and translated by Diwakar Acharya. See Garsha Young Drukpa Association (YDA), Garsha, Heart Land of the Dakinis, 135 .

39 The iconography of the Sugatisamdarśana Lokeśvara is especially found in Kashmir in the 1oth and 11th centuries, but the Triloknath image is not as elegant and delicate as the bronze sculptures of that time. 
in Triloknath. It seems to display only some similarities with the dark stone sculpture, such as the clear-cut eyebrows, the fringes on the forehead, and the crown type, but it certainly shares common features with Kashmiri examples of the late 7 th/8th centuries. This early date certainly supports the local belief that the marble head (or rather the whole sculpture, now lost) already existed, was worshiped, and was blessed by Padmasambhava when he allegedly passed through Lahul on his way to Tibet, stopping at the spectacular site of Ganghola. O.C. Handa states that the pre-eminent position of Gandhola is mainly due to Padmasambhava's visit there. He maintains that:

the popular tradition of the area and the Terma references are unambiguous about that. The Pad-ma bKai Thang states that the 'Padma' happened to meditate at 'Gandhola' before embarking upon his Tibetan odyssey. Padmasambhava might have acquired supernatural tantric faculties after meditating at this place. It was the application of those faculties in Tibet that he could command a reverential status of the Second Buddha. ${ }^{41}$

\subsection{Kinnaur}

The role of Padmasambhava in Kinnaur today is also mainly restricted to the image of a Tantric master and magician who brought Tantric Buddhism to the region by taming the demons-Kinnaur allegedly has the highest number of powerful local deities in the Western Himalayas. ${ }^{42}$ Handa states that:

The Dharma that Padmasambhava preached was apparently not much different from the already existing cult-system in that region. In the scheme of his 'unreformed' religion, there was emphasis on the propitiation and appeasement of the demons in their fierce aspects, which also included several indigenous sacraments. Therefore, the type of Buddhism that has come to stay in major part of Kinnaur is in no way different to its primitive form that Padmasambhava propagated, and it is considerably different in practice to the one prevalent in Spiti, Ladakh and [the] rest of the Tibetan world. ${ }^{43}$

According to Handa, in Kinnaur there is now a stronghold of twelve monasteries of the Nyingma School (Tib. rnying ma pa), the oldest of the four major schools of Tibetan Buddhism that traces back its origins to Pamasambhava.

41 Handa, Buddhist Monasteries of Himachal, 123.

42 Ibid., 18 o.

43 Ibid. 
At the village Nako, close to the Tibetan border, the Guru lha khang is a small temple situated just beside an high-altitude water basin, built around a rock with imprints said to have been miraculously left by Padmasambhava (fig. 6.3). ${ }^{44}$ According to Luczanits, ${ }^{45}$ who studied the heavily damaged murals and sculptures of the interior, and Kurt Tropper, ${ }^{46}$ who transcribed and translated the inscriptions and captions found in the temple, it is difficult to decipher any "unambiguous historical information on the founding of the monument, its decoration or even school affiliation." ${ }^{\prime 7}$ Based on stylistic comparisons with wall paintings from Ladakh, Luczanits suggests a date in the late 14th century and an affiliation to the Drigung Kagyü order, which promoted the teachings of Padmasambhava, by the late 13th century particularly in Ladakh. He further emphasises the small shrine and its decoration in a local painting style as "the only major example preserved in the Spiti Valley" that "supersedes the comparable Ladakhi monuments." 48

The uniqueness of the Guru Lha khang for the local population is not based on its extraordinary decoration, but on the presence of the stone imprints identified by the village tradition as the footprints not only of Padmasambhava but also of the local god Purgyal. ${ }^{49}$ Natasha Kimmet uses the term "touch relics" (earlier introduced by Deborah Klimburg-Salter for hand- and footprints of lamas on the verso of thangkas) to define the semiotic value of these sacred markers. ${ }^{50}$ Touching the signs on the rock that indicate the physical appearance of the god and the guru at that place, promises blessings and merits to the worshipers and pilgrims. The small monument is built around these precious marks, and the architectural structure of the edifice follows the necessity of enshrining them in the centre. The topographical features of the landscape

44 Handa, Buddhist Monasteries of Himachal, 186. Handa reports that according to local belief, these are the landing marks from when Padmasambhava flew on his tiger to the rock in Nako.

Christian Luczanits, "The Nako Monuments in Context." In Nako. Research and Conservation in the Western Himalayas, ed. Gabriela Krist (Vienna: Böhlau, 2016), 36-39.

46 Kurt Tropper, "Inscriptions and Captions in the Gu ru Lha khang at Nako, Kinnaur." In Tibetan Art and Architecture in Context, PIATS 2006: Tibetan Studies: Proceedings of the Eleventh Seminar of the International Association for Tibetan Studies, Königswinter, edited by Erberto Lo Bue and Christian Luczanits (Halle: International Institute for Tibetan and Buddhist Studies, 2010), 143-174.

47 Luczanits, "The Nako Monuments in Context," 39.

48 Ibid., 40.

49 Natasha Kimmet, "Architectural Palimpsets: Exploring Matters of Production, Inhabitation and Perception in the Vernacular Architecture of Nako." In Nako. Research and Conservation in the Western Himalayas, ed. Gabriela Krist (Vienna: Böhlau, 2016), 64. Ibid., 64 . 


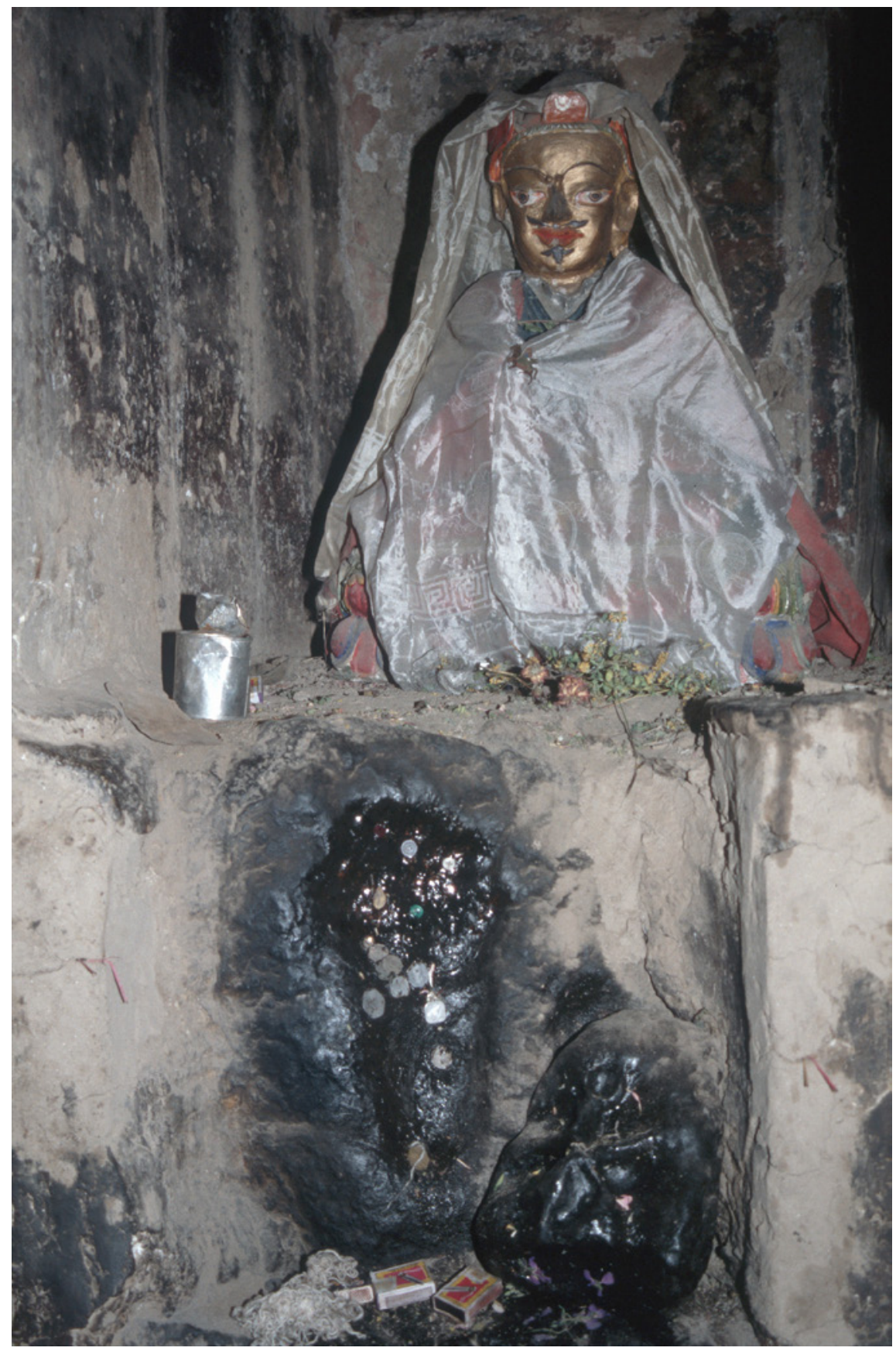

FIGURE 6.3 Imprints of Padmasambhava. Guru Temple (Tib. lha khang) in Nako, Kinnaur. DEBORAH KLIMBURG-SALTER, 1998, WHAV 
(the rock with marks next to the lake) are the determining factors and the spiritual trigger for the establishment of this religious building.

Kimmet further notes that the settlement of Nako developed within defined sacred boundaries, with the Guru Lha khang at the corner of the Nako lake and the sacred Buddhist compound, consisting of four temples at the northwest of Nako, constituting the earliest structural parameters of the village. ${ }^{51}$ Four caves in the vicinity of Nako are furthermore identified as Padmasambhava meditation caves, where he also gave disclosures to his followers.

The heritage of Padmasambhava in Kinnaur is not directly connected to its material culture, but rather to the spiritual energy of special spots and sites in the area. The territory becomes sanctified by the attribution of certain places to the miraculous acts of the guru-resulting in a network of places for worship, and a geography of artistic and religious infrastructure, geared to the needs of pilgrims. However, none of these establishments can be dated on an art historical analysis back to the 8th century.

The Living Tradition of Rinchen Zangpo in the Kinnaur and Lahul Valleys

Alex McKay points out that the strong dominance of Buddhist establishments at the western fringes of the Guge Kingdom (11th-17th c.) is "an early phase of Buddhist propagation in the first Millennium $\mathrm{CE}^{\prime 52}$ - a phase that was initiated by Padmasambhava and brought to full blossom by Rinchen Zangpo and the renaissance of Mahāyāna Buddhism credited to King Yéshe Ö in the third quarter of the 1oth century. Twenty-one minor Buddhist foundations are mentioned in the biography of Rinchen Zangpo; ${ }^{53}$ one of them is supposedly situated in Lahul; seven of them are identified in the region of Kinnaur: the temples of Chulling, Ropa, Poo, Kanam, Kamru, Thangi, and Charang/Tsarang. The latter three are part of the Kinner Kailash circumambulation route.

The foundation of a relatively large amount of Buddhist shrines in an area that is often considered by scholars as being situated at the periphery of the Guge Kingdom must be seen as a strategic stroke. McKay sees the establishment of the religious sites along the already existing Kinner Kailash circumambulation route as a territorial definition enacted by the Buddhist reformers,

\footnotetext{
$51 \quad$ Natasha Kimmet, "Architectural Palimpsets," 63.

52 McKay, Kailas Histories, 179.

53 David L. Snellgrove and Tadeusz Skorupski, The Cultural Heritage of Ladakh, Vol. 2: Zangskar and the Cave Temples of Ladakh (Warminster: Aris and Phillips, 1980), 87.
} 
with the mountain as the frontier. ${ }^{54}$ Thakur even points out that the monastic network "in an agriculturally potential area such as Thangi and Tsarang [...] was essential for the sustenance of the Buddhist communities."55

\subsection{Kinnaur}

All seven monuments ascribed to Rinchen Zangpo in Kinnaur are called Lotsawa Temple (Tib. lo tsa ba lha khang) by the local community, honouring the Great Translator and indicating their foundation and close relation with Rinchen Zangpo. ${ }^{56}$ Despite major changes in their original structure and decoration - the temples were extended, restored, partly reconstructed, repainted, and refurbished-there is still enough archaeological and art historical evidence that indicate a foundation date during the time of the so-called second diffusion of Buddhism. In particular, an astonishingly substantial corpus of clay sculptures - mainly life-size, or slightly over life-size, non-portable objects - can be found in nearly all of these temples (sometimes still attached to the wall, as in Charang). They give vivid testimony of early Buddhist iconographic/iconologic programmes and stylistic inspiration from the art of Kashmir. 57

The legacy of Rinchen Zangpo is still ubiquitous in Kinnaur. His presence is firmly established not only through existing material culture but also through oral traditions such as ritual speeches or folk songs. Thakur recorded songs related to the Great Translator in several villages of Kinnaur, including Ribba, Ropa, and Kanam..$^{58} \mathrm{He}$ calls these songs, consisting of up to ninety stanzas, "almost stable texts" that:

have been memorized, repeated and handed down generation to generation, thus avoiding to considerable extent obliteration during the last one thousand years. ${ }^{59}$

It is interesting to note that the oral tradition of Kinnaur shifts the birth place of Rinchen Zangpo from Khatse (Tib. Khwa tse) in Ngari (today Western Tibet)

\footnotetext{
54 McKay, Kailas Histories, 180.

55 Thakur, "Rin chen Bzang po's Footsteps," 212.

56 Alternative names of local deities are also possible, e.g. Rangrik monastery (Tib. Rang rig rtse mgon pa) in Charang.

57 For a detailed study and classification of the clay sculptures in Himachal Pradesh and Ladakh see Christian Luczanits, Buddhist Sculpture in Clay: Early Western Himalayan Art, late 1oth to early 13 th Centuries (Chicago: Serindia, 2004).

$5^{8}$ Thakur, "Rin chen Bzang po's Footsteps," 212-216.

59 Ibid., 112 .
} 
to Sumra, a small village at the district border between Spitī and Kinnaur. This might be for not only legitimisation reasons but also due to the fact that the 18th incarnation of Rinchen Zangpo was born there in 1923.

Several of the songs address the building of monasteries and Buddhist shrines, sometimes giving conceivable logistic information on transport of construction material, such as wood and stones, and the great efforts of the Buddhist samgha to accomplish these works in the inhospitable mountainous region. ${ }^{60}$ Also the miraculous construction of the temple in Ribba in only one night by Rinchen Zangpo himself is sung about, including the legend that after finishing the temple and offering it to the local community, Rinchen Zangpo had to flee from Ribba before he was mutilated or even killed by some wicked inhabitants. ${ }^{61}$ There might be several explanations for why the life of Rinchen Zangpo was threatened by the villagers - that he should be prevented from building a similar monastery, that new Buddhist tendencies were not welcomed, or that people were shocked by the magical powers of the Buddhist reformer. ${ }^{62}$

Interestingly enough, the Ribba Temple, destroyed in a fire in 2006, was the only monument that seemed to be coeval with or slightly later than Padmasambhava's supposed presence in Kinnaur-but it is likely before the 1oth century and the second diffusion of Buddhism. ${ }^{63}$ Located high above the Sutlej River, the original small single-celled temple was integrated into a larger complex, so that the original structure functioned as the cella of the temple in modern times. An external circumambulation path (Skt. pradakșinapatha) placed on an elevated veranda led around the carved walls of the sanctum. The elaborate wooden portal, frequently repainted and covered with whitewash in the last decades, consisted of multiple horizontal registers and vertical doorjambs, decorated alternately with floral scrolls and figurative bands that form small niches, each filled with only one figure. The lintels displayed rows of sitting Buddhas in architectural and ornamental frames. Ribba shared these features with other originally single-celled monuments in the Western Himalayan area, such as the Buddhist shrine of Triloknath (Lahul) and the Hindu shrines

6o Thakur, "Rin chen Bzang po's Footsteps," 213.

61 Ibid.

62 These founding legends are frequently told in similar versions all around Himachal Pradesh e.g. the artist Gugga, famous for his bronze statues from Brahmaur in Chamba, is said to had to leave the region after he built the wooden temple of Śaktī Devī in the $7^{\text {th }}$ century. O.C. Handa, Woodcarving in the Himalayan Region (New Delhi: Indus Publishing Company, 2006), 58-59.

63 For an art historical assessment of the temple see Klimburg-Salter, "Ribba, the Story of an Early Buddhist Temple in Kinnaur,"; and Luczanits, Buddhist Sculpture in Clay. 
of Udaipur (Lahul), Chhatrarhi and Brahmaur (Chamba), and Nirmand (Kulu). All six monuments can be dated to an early period and are situated on important regional and trans-regional pilgrimage routes. ${ }^{64}$

The destroyed temple was recently rebuilt, intended as a reconstruction of the original structure, consisting of a single-celled monument without the attached assembly hall for the monks (fig. 6.4). But the extensive building activity around the wooden temple suggests that in the near future, there will be a large compound of several massive (concrete) edifices for the samgha, that indeed will strengthen the Buddhist community and the role of Ribba as a religious centre in present times. Based on old photographs and drawings, an effort was made to copy the original carvings of the wooden portal in order to imitate an authentic impression of the ancient monument. The result is certainly debatable from an aesthetic and conservational point of view. One can notice that the reconstruction work on the Ribba temple takes part in a recent regional renovation and enlargement process of numerous Buddhist and Hindu wooden shrines in Kinnaur. ${ }^{65}$ Workshops from Nepal were supporting the local craftsmen, mixing new elements with traditional motifs, and creating a certain uniformity of the hitherto unique monuments. This might be inaccessible to our historic and nostalgic mind, but in the case of Ribba, it might cause a new spiritual and ritual impetus at the site. This new temple underlines that the old temple was - and the new building still is - a highly appreciated reminder of the activities of Rinchen Zangpo in former times.

The temple was inaugurated in 2016, with a big ceremony and in the presence of the 19th and current incarnation of Rinchen Zangpo, namely Tenzin Kalzang Lochen Tulku Rinpoche (Tib. bsTan 'dzin kal bzang lo chen sprul sku rin po chen) (fig. 6.5). His religious home is the Kyi Monastery in the Spìtī

64 The temple in Ribba is part of the circumambulation route of the Kinnauri Kailash (known locally as Kinner Kailash), which encircles the mountain considered sacred by both Hindu and Buddhist Kinnauris. The route, stretching over two hundred kilometres, is performed clockwise, visiting the local sanctuaries on the way. Although of probably more ancient origin, Klimburg-Salter refers to a tradition that attributes all important sites and monuments on this route to the great translator Rinchen Zangpo, as a replication of his own travel from Guge to Oḍḍiyāna. See for that Klimburg-Salter, "Ribba, the Story of an Early Buddhist Temple in Kinnaur," 7 .

65 It all started when the wooden temple of the Badri Narayan Temple in Batseri in the Sangla Valley was destroyed in a fire around 200o. It was rebuilt by the local community, very loosely following the traditional structure of stone interspersed with wooden beams. For the wooden carvings, the local community engaged local workshops from the neighbouring valleys as well as Nepalese craftsmen, which produced, among other extraordinary motifs, a rather Baywatch-like erotic frieze. However, the rather unusual aesthetic of the new temple and the wooden carvings became famous in the region and are highly appreciated by the local people. This appreciation resulted in a series of renovations of other local village shrines in the surrounding region. 

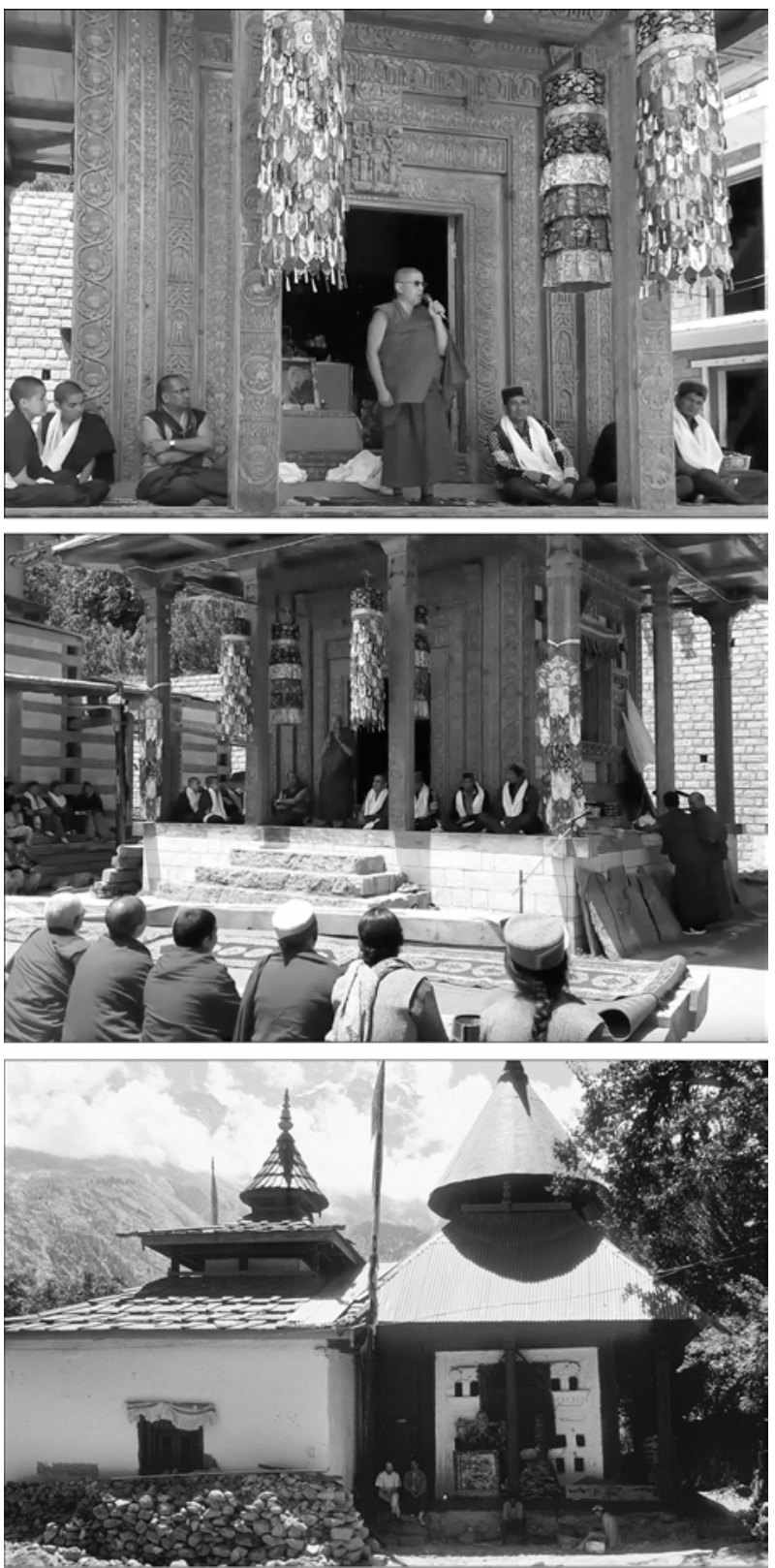

FIGURE 6.4

Lotsawa Temple (Tib. lo tsa ba lha khang). Ribba,

Kinnaur. Restored in 2016 (top and middle) and before destruction in 1994 (bottom). SOURCES RESP. <HTTPS:// WWW.YOUTUBE.COM/ WATCH?V=NFDSKNJPQHC $>$ (2:57 AND 2:43); DEBORAH KLIMBURG-SALTER, 1994, WHAV

Valley, his other headquarters is in Delhi, where he holds a political office. Nevertheless, he spends considerable time in Kinnaur and Spìtī, being a representative at various religious festivities in the region. He is highly esteemed among the community, and his status as the Great Translator's incarnation grants him authority. Christian Jahoda, who examined the authoritative speech tradition 


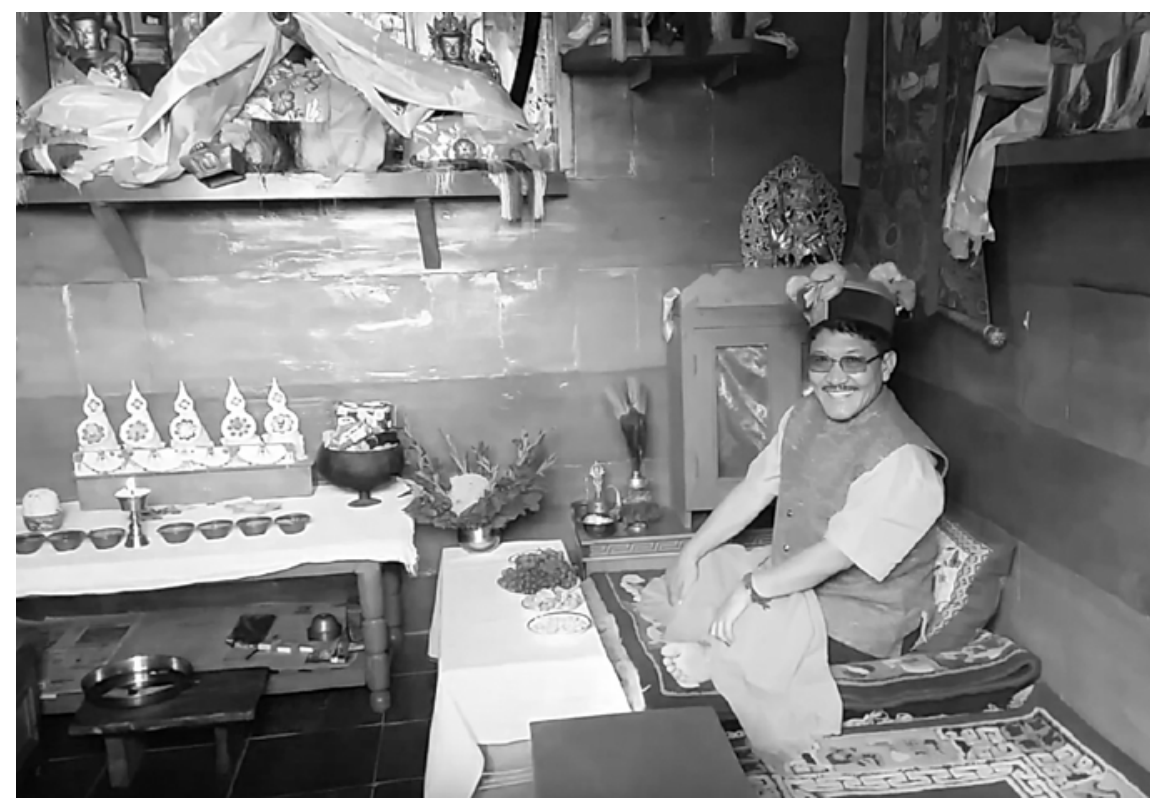

FIGURE 6.5 Tenzin Kalzang Lochen Tulku Rinpoche, the 19th incarnation of Rinchen Zangpo inside the restored Lotsawa Temple in Ribba, 2016.

$<$ https://www.youtube.com/watch?v=ht6ggoKPZog>_(2:50)

(Tib. mol ba) in Spìtī and Kinnaur, refers to an incident at an assembly with the trance medium of Tabo, who "reminded and admonished to hold the present incarnation of the Great Translator Rinchen Sangpo in high esteem (notwithstanding the fact that he had married and become a political figure)."66 In this speech, only the Dalai Lama was placed above Lochen Tulku Rinpoche, putting him on the same level as a bodhisattva.

\subsection{Lahul}

The local tradition of Lahul dates four temples to the time and person of Rinchen Zangpo, two small shrines in the Bhaga Valley, Gumrang and Johling, and two in the Chandra Valley, namely a small house temple in Choskhor and a shrine in Gondhla (not to be confused with Gandhola), which had been thrice rebuilt since the 1oth century. ${ }^{67}$

Only one site in Lahul, namely Johling (fig. 6.6), just opposite Kyelong, directly on the left bank of the Bhaga, can actually be identified as one of the

$66 \quad$ Christian Jahoda, "Imparting and (Re-)Confirming Order to the World: Authoritative Speech Traditions and Socio-political Assemblies in Spītī, Upper Kinnaur, and Purang in the Past and Present," Oral Tradition 30.2 (2016): 336.

67 Garsha Young Drukpa Association (YDA), Garsha, Heart Land of the Dakinis, 47. 


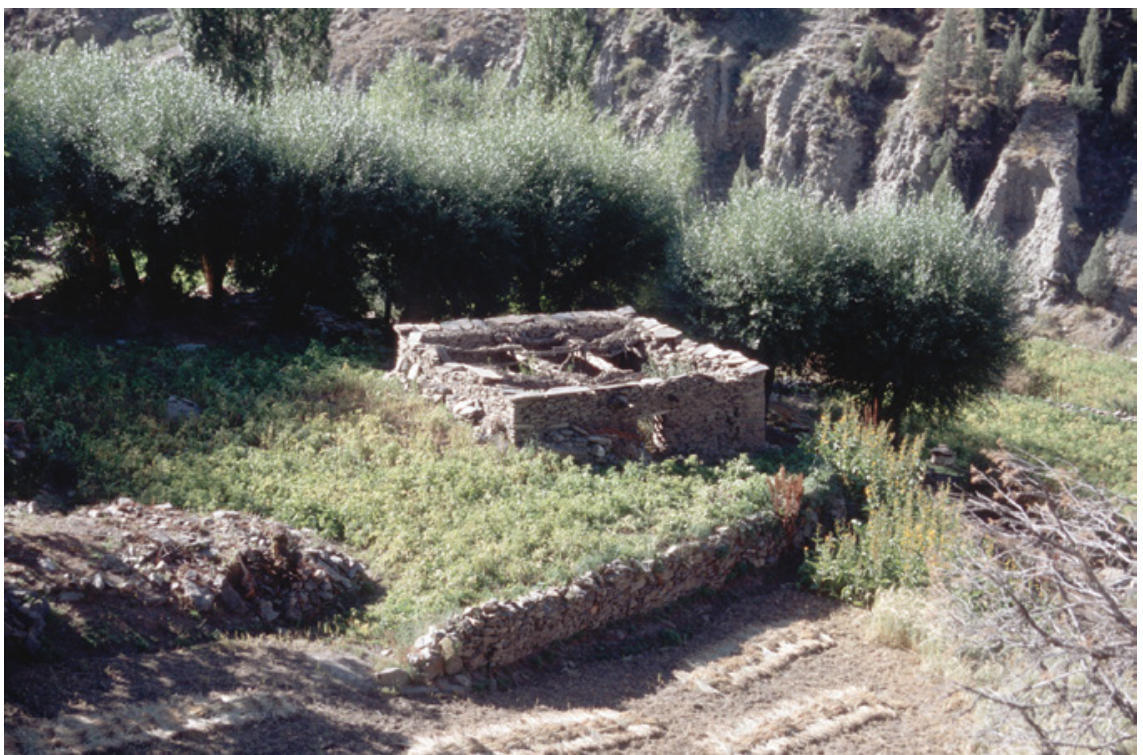

FIGURE 6.6 Dilapidated shrine. Lha Lama Temple (Tib. lha bla ma lha khang). Johling, Lahul. Dated to the time of Rinchen Zangpo.

VERENA WIDORN, 2002, WHAV

twenty-one minor foundations mentioned in the biography of the Great Translator. Visiting and documenting the site in 1991, Klimburg-Salter ascertained that the temple was named by local people Lha Lama Temple (Tib. Iha bla ma lha khang), which she associates with Lha lama Yéshe Ö (Tib. Lha bla ma Ye shes 'od). ${ }^{68}$ The single-celled temple of Johling, built on a square ground plan, is nowadays totally ruined. Although the building had not been in ritual use any more, the local people used to decorate the interior with flowers, at least up to the 1990 os. ${ }^{69}$ Fifteen years ago, the monument, after increasing decay, was covered with a new tin roof to slow the decay. The original simple structure of the temple consists of massive stone walls interspersed with thick wooden beams, a typical traditional Lahuli method of construction that can be also seen in Gumrang. The former flat roof was supported by two wooden pillars and gave shelter to at least two wooden sculptures, a Buddha Śākyamuni under the bodhi tree (now housed in the Bhuri Singh Museum in Chamba) and an Amitābha (now in the British Museum in London) ${ }^{70}$ that can be dated to the

68 Deborah Klimburg-Salter, "Tucci Himalayan Archives Report, 2," 46-48.

69 In 1991, Klimburg-Salter noticed the annual harvest offering laid before the location of an ancient altar. See ibid., 46-50.

70 The wooden Amitabha from the British Museum was one of the acquisitions of Walter Asboe, knowing them from a photograph that Shuttleworth had taken in 1923 (now kept 
late 1oth or early 11th century, due to stylistic features. ${ }^{71}$ In their publication, the Garsha Young Drukpa Association expresses regret and some lack of understanding that the villagers let the temple rot, and that the wooden sculptures were removed from the area and cannot be venerated in situ anymore:

May the story of Joling remind us to treasure deeply the priceless spiritual heritage of Garsha Khandroling, Heart Land of Dakinis! [...] Our present pilgrimage does not allow us to receive their [the two wooden Buddha sculptures] blessings, but we can remember them. ${ }^{72}$

By raising the shrine and its former wooden decorations to the status of a memento mori, the ruin and the sculptures remain anchored in the memory of the local population, as precious creations of Rinchen Zangpo.

Based on stylistic evidence, especially the sculptural decoration, which consists of several badly preserved clay statues, the sanctuary of nearby Gumrang is considered by art historians to be of a later date (probably 12th century) than is believed by the locals. ${ }^{73}$ The small hamlet, also called Tonpa Gompa (Tib. ston pa dgon $\mathrm{pa}$ ), is in a fragile state; the murals are mainly gone and the small bits and pieces of the former textile ceiling decoration are in a woeful condition. The temple was almost collapsing about eighty years ago, ${ }^{74}$ forcing the locals to take out the fragile clay sculptures that were originally attached to the main wall in a mandala-like composition. ${ }^{75}$ The sculptures, (fig. 6.7) or as it turned out later, the local spirits of the place, were against the removal and were whispering, weeping, and howling so loud that the terrified villagers returned the objects, just placing them side by side against the wall and leaving the building untouched, as they were instructed by the spirits. ${ }^{76}$ This story elu-

in the British Library and in the Kern Institute in Leiden). Asboe purchased the sculpture from the local lama for around 65 Rupees, being aware of the fact that this enterprise had to be done secretly, without informing local authorities or the Buddhist community (see letter by Asboe 1933, unpublished, Moravian Missionary Archive, London).

Verena Widorn, "Buddha Śākyamuni, Johling (Kyelong), Lāhaul and Spītī," in Vision of an Enlightend King, A Centenial Bouquet of Himalayan Art from the Bhuri Singh Museum Collection, ed. Vijay Sharma (Chamba: Bhuri Singh Museum, 2008), 52-53.

72 Garsha Young Drukpa Association (YDA), Garsha, Heart Land of the Dakinis, 48-49.

73 Luczanits, Buddhist Sculpture in Clay, 107-112.

74 Garsha Young Drukpa Association (YDA), Garsha, Heart Land of the Dakinis, 50.

75 Two photographs taken by H.L. Shuttleworth in the 1920s and now kept in the British Library, London, show the former position of the clay sculptures attached to the main wall with the four-headed Vairocana in the centre (see also Widorn, "Traversing the Land of Siddhas and Dakinis," 200, 201). One of the photographs was recently published by Laurent, "Henry Lee Shuttleworth (1882-196o) and the History of Spiti," 14.

76 Garsha Young Drukpa Association (YDA), Garsha, Heart Land of the Dakinis, 5 o. 


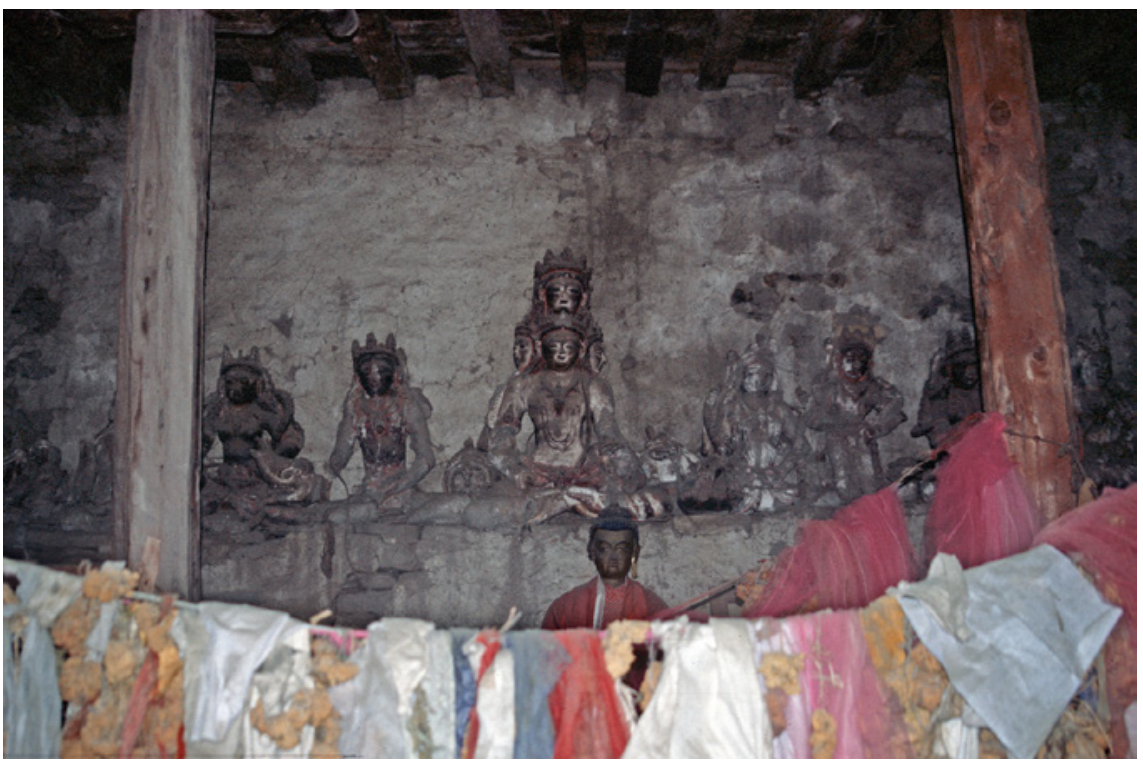

FIGURE 6.7 Interior and clay sculptures of Tonpa Gompa (Monastry). Gumrang, Lahul. Dated to 12 th century.

VERENA WIDORN, 2002, WHAV

cidates the current rather unusual line up of the sculptures, ${ }^{77}$ and probably also some of the damage to the clay figures. It might also explain why the temple, as one of the oldest monuments in the region and although still in use and veneration, is slowly decaying. In contrast, two simple stüpas in the vicinity of the Gumrang shrine (fig. 6.8) are still in good shape. Both stüpas are built of irregular stones stacked over one another to provide square platforms (Skt. me$\mathrm{dhi}$ ) and a round dome (Skt. anda); the upper part of the smaller stüpa seems to be totally missing. The larger structure has a further small square platform (Skt. harmika) topped by a wooden umbrella (Skt. chhatri). Obviously the two monuments are also directly attributed to Rinchen Zangpo, who according to local narrations was asked by the villagers to construct them for the protection of their houses, which were frequently swept away by avalanches. ${ }^{78}$ With regard to their good state of preservation, and in comparison to the clay sculptures of Gumrang, one can only agree with the local perception:

77 This formation has even led to some misinterpretation with regard to the original position of the sculpture. See e.g. Luczanits, Buddhist Sculpture in Clay, 108, and Garsha Young Drukpa Association (YDA), Garsha, Heart Land of the Dakinis, 5o, who assume that the sculpture of the Buddha Vairocana had been placed in the middle of the room, surrounded by the other figures each facing a cardinal direction.

78 Garsha Young Drukpa Association (YDA), Garsha, Heart Land of the Dakinis, 51. 


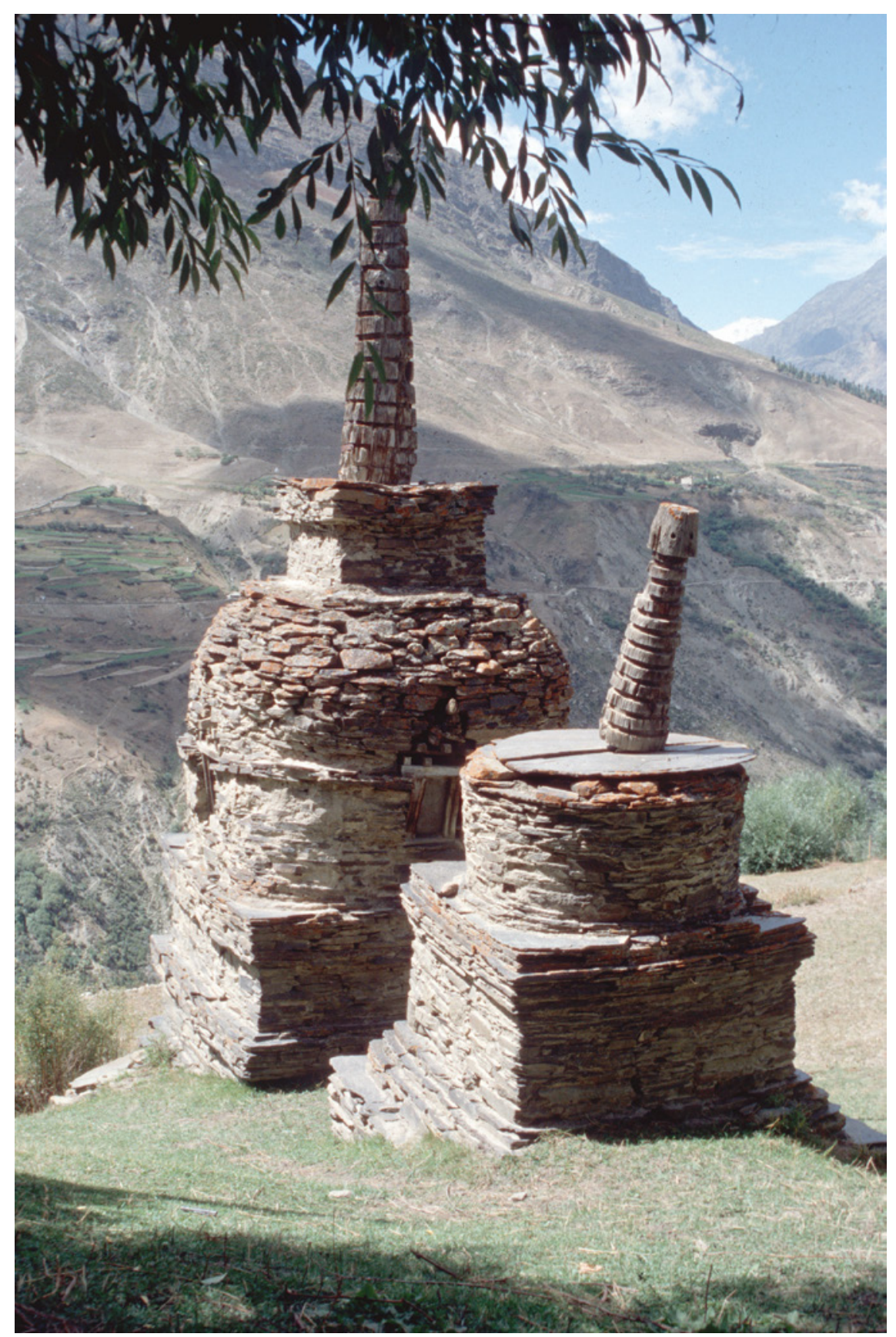

FIGURE 6.8 Old stone stūpas. Near Gumrang, Lahul. Dated to the time of Rinchen Zangpo. VERENA WIDORN, 2002, WHAV. 
The fact that this ancient stupa still stands after so many centuries demonstrates in itself powerful protection, and also supports the wisdom saying that stupas are even holier than statues. ${ }^{79}$

In any case, the stüpas are firmly rooted in the landscape and could not be removed from their position, since the location is part of their function as an emblem of a more than a thousand-year long protection against natural catastrophes.

The religious environment encountered by Tibetan pilgrims such as Gö Tsangpa, when traveling through the Western Himalayan region in the 13th century, was marked by monuments and artefacts of the Ngari Kingdom and Mahāyāna Buddhism. Nevertheless, neither well-known religious institutions nor important monasteries of that time seem to have attracted special attention from these pilgrims. Despite the difficulties of allocating the spellings of names in the pilgrims' travelogues to today's villages and real places, and thus of reconstructing the itineraries in detail, one can notice that many monastic sites are not mentioned.

\subsection{Kinnaur}

There is not much information on the travels and sojourns of Gö Tsangpa in Kinnaur, based on his itineraries translated by Tucci. ${ }^{80}$ The hagiography states that after having crossed Zhang Zhung, the Tibetan pilgrim went to Spìtī, after stopping at the "temple in To ldin [Tholing] in Zan zun where he saw the residence of Atisa and Lha bstun Byan c'ub od." ${ }^{81}$ He then seemed to proceed to a place called Bichok (Tib. Bi lcogs) that Tucci cautiously identifies as Pilche in the Lipak Valley opposite Nako, where the great siddha Karagpa (Tib. Ka ra pa) had been meditating for thirty years. ${ }^{82}$ His further encounters with other siddhas in this area are not fixed to any particular location, and it seems that the story illustrates different ways of meditation that the yogi was confronted with on his travels.

79 Garsha Young Drukpa Association (YDA), Garsha, Heart Land of the Dakinis.

80 Tucci, Travels of Tibetan Pilgrims in the Swat, 15-17.

81 Ibid., 16.

82 Ibid., 16-17. 
There are some reasonable doubts that Gö Tsangpa traversed Kinnaur on his way to the West (he probably took the northern route over Spītì), as there is hardly any tradition of worshiping the great yogi in this area.

\subsection{Lahul}

In Lahul, a dozen of small monasteries have been erected on the slopes of the hills of the Bhaga Valley in the last centuries, on both sides of the Bhaga River overlooking the valley. Based on different sacred biographies (Tib. nam thar) and oral transmissions, the local tradition relates several of these sites to famous religious personalities of the Drukpa Kagyü order, who lived from the 13th century onwards - especially to the Tibetan pilgrims Gö Tsangpa and his followers. ${ }^{83}$ Toni Huber sees the transfer of pilgrimage routes from northern India to the Himalayan region in the early 13 th century as the implementation of new spiritual concepts-such as the search for the vajrakāya in the Indian mountainous region. For him, this time is the point of departure for a new Tantric Buddhist pitha system, with twenty-one external locations, spanning from Western Tibet to the Hindukush. ${ }^{84}$ Gö Tsangpa belonged to the first generation of Tibetans who ignored the importance of the eight great sites in the Ganges plain, directly connected to the eight major events in the Buddha's life. He and his adepts, such as Orgyenpa, followed the new tradition, in which they performed their inner and outer ritual journey in the mountainous regions of the wide Himalayan range. Huber thinks that common Hindu sites and symbols, as well as spiritual places associated with local deities, were adopted by the Buddhist Tantric system to create a pițha network in the Himalayan region, consisting mainly of Śaiva and Śākta sites. ${ }^{85}$ This phenomenon is especially true with Lahul, as evidenced by the numerous sites still worshiped by Hindus as well as Buddhists, such as the Gandhola cremation ground or the joint veneration of the main idol of Triloknath. The journeys of the Drukpa Kagyü pilgrims through the Western Himalayan region were certainly marked by an ideological return to Tantric Buddhism attributed to Padmasambhava (and suppressed by the Guge rulers in the 1oth and 11th centuries).

From the travel itinerary, we can assume that the Tibetan pilgrims were primarily looking for extraordinary places in remote, sparsely populated areas,

83 For a detailed description of the routes, see Giuseppe Tucci, Travels of Tibetan Pilgrims in the Swat, 15-17; and Verena Widorn, "Traversing the Land of Siddhas and Dakinis—Art Historical Evidence along the Buddhist Pilgrimage Routes through Lahul," in Cultural Flows across the Western Himalaya, ed. Patrick McAllister, Christina Scherrer Schaub, and Helmut Krasser (Vienna: Austrian Academy of Sciences, 2015), 189-235.

84 Huber, The Holy Land Reborn, 109.

85 Ibid. 


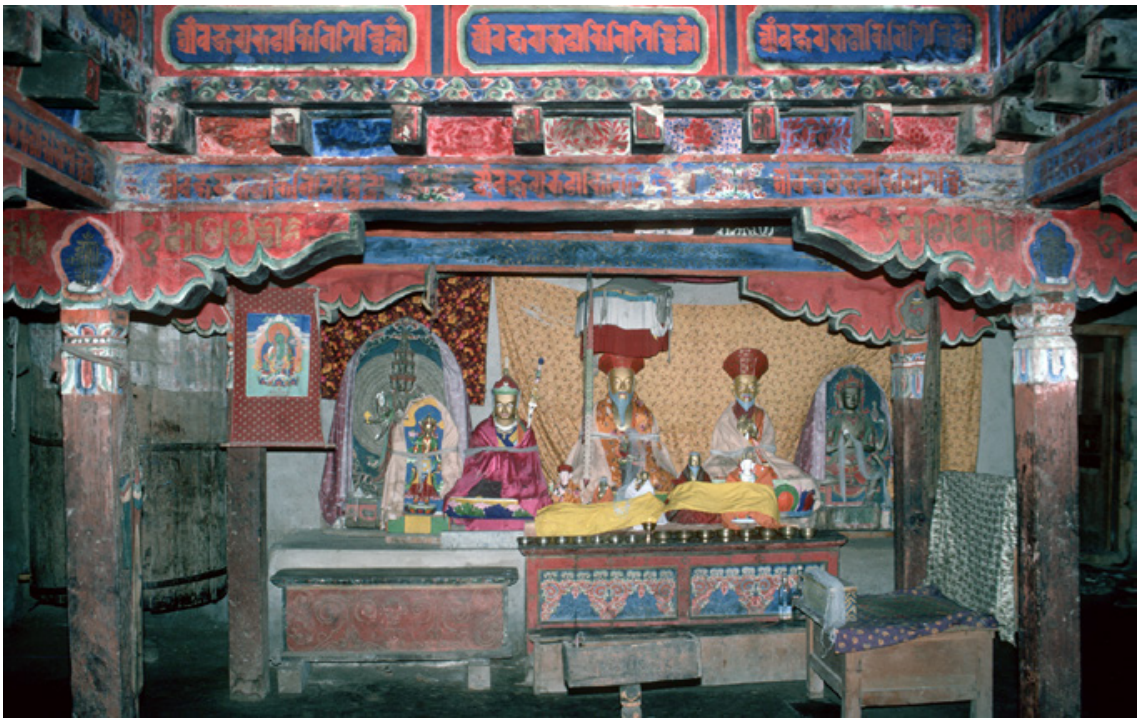

FIGURE 6.9 Local Drukpa Kagyü lineage with Padmasambhava (left), sculptures in the monastery of Gandhola, Lahul.

CHRISTIAN LUCZANITS, 1993, WHAV

where the connection with nature became the most critical part. ${ }^{86}$ The Buddhist institutions built up by the royal family and Rinchen Zangpo at the time of the second diffusion of Buddhism seem to have played only a minor role for the pilgrims, as there are hardly any references in their travelogues to places such as Johling or Gumrang. Instead, according to his itinerary, Gö Tsangpa preferred to retreat to high mountain levels and to meditate in caves or in natural surroundings. ${ }^{87} \mathrm{He}$ was probably impressed by the narrow Bhaga Valley in Lahul and the breath-taking view from the slopes of Mt. Drilbu over the confluence of the rivers at Gandhola-similar to his religious ancestor Padmasambhava, according to the local imagination. ${ }^{88}$ In the shrine of Gandhola, this spiritual connection is symbolised by a row of small statues presenting Padmasambhava in a direct lineage with two Drukpa Kagyü yogis (fig. 6.9).

86 See Widorn, "Traversing the Land of Siddhas and Dakinis," 229, 230.

87 Garsha Young Drukpa Association (YDA), Garsha, Heart Land of the Dakinis, 63.

88 The Garsha Young Drukpa Association also emphasise that Gö Tsangpa sought especially caves of his spiritual forefathers, and locations related to Cakrasaṃvara and Vajravārāhī, as his guru was an emanation of Cakrasaṃvara. See ibid. The mahāsiddha Ghāṇțapa is said to have turned the peak of Mt. Drilbu into the centre of a mandala of Cakrasamvara by performing sexual union with his consort. See Stutchbury, Rediscovering Western Tibet, 46 . 
The sanctification of the landscape through spiritual journeys and wondrous actions is at the forefront of the formation of local myths spinning around the Tibetans' pilgrimages. Here, too, it is above all the territorial markings of the imprints that were left in rocks by the yogis, and which are regarded as clear signs of their physical presence in former times. They can be also regarded as symbols of their miraculous power, as some are considered to be starting or landing marks when the yogis were flying through the air. At a later date, shrines and monasteries were built around them and form the requisite religious infrastructure for the numerous devotees. For Gö Tsangpa, the Garsha Young Drukpa Association reports that:

Today, his most popular legacy and source of grace are the many miraculous imprints of his body that he embedded in rocks. Around Drilbu Ri, at least six sites are hallowed in this way: Sila cave, Sila Gompa, Kardang Jhabje, Gotsang village, Biling and Yurdong cave. All of them have been turned into shrines, temples or monasteries. ${ }^{89}$

All the mentioned shrines were repeatedly renovated or substantially expanded in the last centuries, and there are no more traces of ancient remains that might have supported an early foundation date. The monuments and caves are spectacularly located on both sides of the river, high on the mountain slopes overlooking the entire Bhaga Valley. The Yurdong Monastery is harmoniously embedded into the steep mountainside beneath an overhanging cliff, which shows the close connection between architecture and nature, and the quite deliberate fusion of art with landscape (fig. 6.10). Special topographical features such as "[...] the strange remains of a dry tree" are associated with "some firewood that had only half burnt [... and] got stuck" when Gö Tsangpa crossed the Bhaga Valley with just one stride between Yurdong and Gotsang..$^{90}$ The flights or jumps of the Tibetan yogi over valleys and long distances not only explain the imprints in the landscape, but also create a network of buildings, which are located on both sides high above the river and the villages, partly within sight. The distances between these sites are not to be measured by normative standards but with spiritual ranges that tie the spots together.

At the beginning of the 17th century, when Taktsang Répa travelled through Lahul and especially the Bhaga Valley, the region was already a religious centre of the Drukpa Kagyü School. Taktsang Répa spent several months in this

89 Garsha Young Drukpa Association (YDA), Garsha, Heart Land of the Dakinis, 63.

$90 \quad$ Ibid., 67 . 


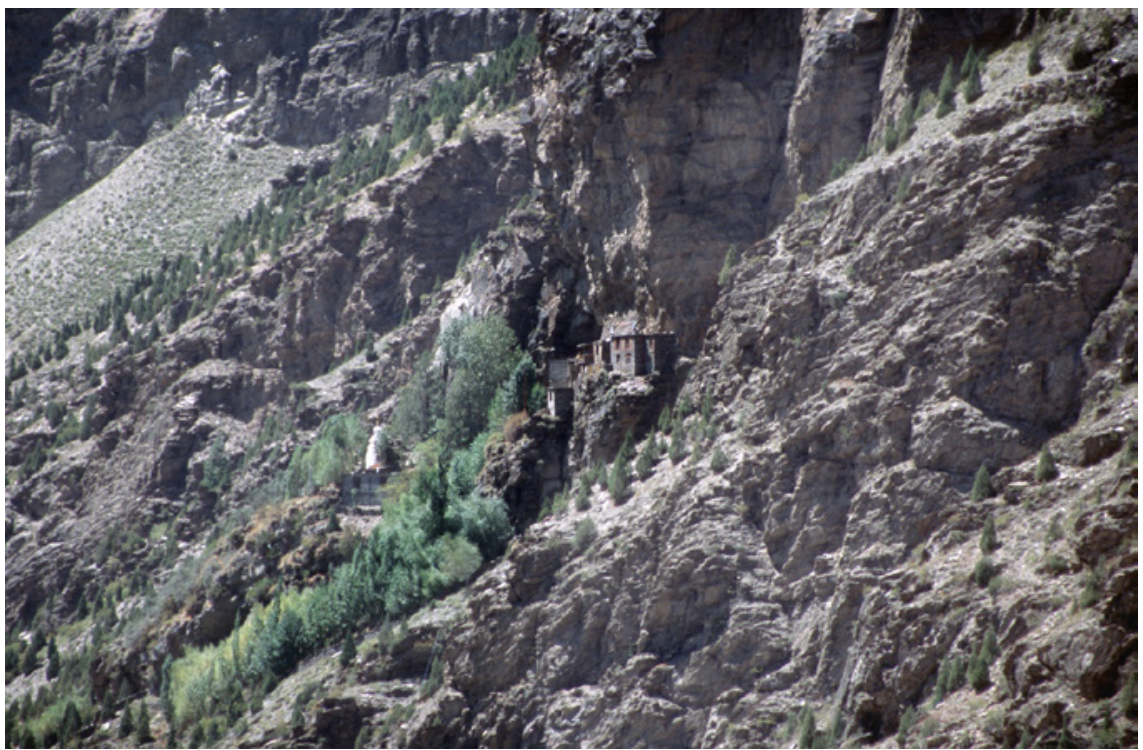

FIGURE 6.10 Yurdong Monastery. Bhaga Valley, Lahul.

VERENA WIDORN, 2017, WHAV

area, including six months in winter in retreat in Yurdong. ${ }^{91}$ The Garsha Young Drukpa Association explains that the monastery of Yurdong had to be gradually expanded over the centuries "due to the fervent worship of local people as well as the natural influence of great meditators." 92

Several other monasteries in the valley were also renewed in the last decades, partly dismantled and reconstructed with new colourful woodcarvings and wall paintings. The historical substance and ancient wall paintings may be largely lost, but the veneration and worship of the Tibetan yogis is still vivid in the iconography of the murals. Conversely, the temples associated with Rinchen Zangpo are slowly collapsing.

\section{Conclusion}

Many temples (up to an auspicious number of 108) are said to have been founded by Rinchen Zangpo throughout the Western Himalayan region-but not all of them are valued with the same esteem. Kinnaur, on the one hand,

91 Tucci, Travels of Tibetan Pilgrims in the Swat Valley, 410-411.

92 Garsha Young Drukpa Association (YDA), Garsha, Heart Land of the Dakinis, 67. 
seems to have remained a stronghold of Tibetan Buddhism, introduced by King Yéshe Ö and Rinchen Zangpo at the turn of the first millennium. Local beliefs and territorial deities were incorporated and religious centres institutionalised, keeping and cementing the superior position of Buddhism. The oral tradition strongly supports the long tradition, apotheosizing the Great Translator as the main figure and the shining key agent of this whole development. Even the temple of Ribba, which contained art historical elements suggesting a foundation date prior to the second diffusion of Buddhism, was incorporated in the legendary canon of his activities and monastic foundations.

In Lahul, on the other hand, the religious tradition took a totally different turn, already set in motion by Tibetan pilgrims in the 13 th century. The pilgrims were longing for perfect meditation places, looking for sites with special spiritual power, and seeking to go on retreat to high locations. They obviously found this ideal setting in the landscape of Lahul — a mandala-like topography with the holy Mt. Drilbu in the centre, enclosed by the two rivers Bhaga and Chandra. The pilgrims totally ignored the already existing religious monuments, but were instrumentalised as monastic founders themselves. Several of the pilgrims must have passed Kinnaur on their way from Tibet to Oḍ̣iyāna, but with a much more minor impact on the religious landscape of the region than they had on Lahul.

An interesting and still not fully comprehensible factor in the Buddhist history of the present state of Himachal is the legendary figure of Padmasambhava. The art historical attributions of certain objects and monuments in Lahul and Kinnaur to the supposed life time of Padmasambhava are as varying and hypothetical as the different scholarly interpretations of his actual existence and presence in the Western Himalayas. To our current scientific knowledge, we must consider the numerous legends and miracles surrounding him a construct of various schools and traditions that use this personality for particular purposes, goals, and legitimisation. Of course, this does by not exclude the possible presence of an important Tantric master in the 8th century and his impact on the later Buddhist art and architecture of the Himalayan region.

DaCosta Kaufmann resumes his discourse on the geography of (Western) art with the statement that "history of art lies at the conjunction of the temporal with the spatial" and that "art history's arguments, theories and narratives are ultimately based on locations as well as chronology."93 I would go one step further and argue that art historians have to be aware that in the process of attributing the Himalayan artefacts and monuments to famous personalities, location and topography are strong issues in the local tradition, while chronol- 
ogy and especially the authenticity of origin and patronage became a matter of collective memory and mentality. The date of creation is only important to the extent to which it supports the ideological background and the religious ideals of the assumed patron. The way of perceiving and handling the artistic heritage in the Western Himalayan area may not coincide with the appreciation of western art historians and their quest for authenticity. But to understand certain mechanism and agencies involved in the process of sanctification of the topographical and cultural landscape in the Western Himalayas, might help to distinguish between rural legends and historical facts. It might also help to accept, even in an academic world, the fluent boundaries between the perceptions of mysticality and the reality that keeps the sacred geography and the religious tradition alive. 